\title{
KONVERGENSI AGAMA DAN SAINS DALAM MELACAK BASIS ONTOLOGI SEMESTA: Tinjauan Hermeneutika Hadis Penciptaan
}

\author{
Mustofa Umar \\ Universitas Islam Negeri (UIN) Alauddin Makassar \\ e-mail: tonjie016@gmail.com
}

\begin{abstract}
The main purpose of this article (research) is to provide the unity of coherent conceptual frameworks between religion and science on the discourse about the origins of the universe. Contemporary cosmological theories reveal the continuing encounter between physics and theology (religion). The concepts of modern physics show surprising parallels to the ideas expressed in the religious philosophies that the basic features of their worldview are the same. Mystical traditions are present in all religions and they also can be found in the theory of modern physics on the holistic conception of reality. It obviously indicates a new "paradigm" - a new vision of reality. By the "antinomic" principles of light, both religion and science, ontologically, can trace the beginning of the universe, and also unveil the deepest secrets of the laws of physics. Light as the basic ontology of reality in the hadith texts has been used by muslem theosophists (sufi) to formulate their theories of the universe creation, especially, in the sufism of Ibn Arabi. His cosmological concepts are essentially similar to the scientific conceptions of cosmology and completely in accordance with the laws of physics in the very heart of the cosmos itself. At the moment, the integration of religion and science has arrived at the same holistic conception of reality. As the pillar of civilization, both are expected to go hand in hand and form a powerful force for social change in the new conceptual frameworks for ways of life, thought, and consciousness.
\end{abstract}

Abstrak: Tujuan utama dari artikel (riset) ini adalah untuk membuktikan terdapatnya kesatuan kerangka konseptual yang koheren antara agama dan sains tentang persoalan muasal alam semesta. Teori-teori kosmologi modern menunjukkan adanya titik temu yang berkelanjutan antara sains dan teologi (agama). Konsep-konsep fisika modern memperlihatkan kesejajaran yang menakjubkan terhadap ide-ide yang diungkapkan dalam filsafat agama, yaitu ciri-ciri dasar pandangan mereka yang sama. Tradisi-tradisi mistik yang terdapat dalam agama, juga dapat dijumpai dalam teori fisika modern tentang konsep realitas yang holistik. Ini dapat disebut sebagai paradigm baru-visi baru terhadap realitas. Melalui prinsip "antinomi" cahaya, secara ontologis, agama dan sains keduanya dapat melacak permulaan semesta, juga dapat membuka selubung terdalam dari rahasia hukum alam (sunnatullāh). Cahaya sebagai basis ontology realitas yang terdapat dalam teks-teks hadis, telah digunakan oleh para sufi untuk menformulasikan teori-teori mereka tentang penciptaan semesta, khususnya Ibn Arabi. Secara esensial, konsep kosmologi Ibn Arabi memiliki kemiripan dengan konsepsi dalam sains dan secara sempurna sesuai dengan hukum alam pada aspek yang paling dalam dari kosmos itu sendiri. Saat ini, intregrasi agama dan sains sudah sampai pada kesamaan konsepsi tentang realitas secara holistik. Sebagai pular peradaban, keduanya diharapkan dapat berjalan beriringan dan membentuk sebuah kekuatan penuh bagi perubahan 
sosial dalam bingkai keonseptual baru terhadap pandangan hidup, pemikiran dan kesadaran.

Keywords: religion; science; hadith

\section{A. Pendahuluan}

Jika ditelusuri secara mendalam, pada dasarnya baik agama maupun sains berakar dari perkembangan penalaran manusia dalam menelusuri basis tertinggi realitas semesta. Persoalan mendasar sepanjang sejarah pemikiran manusia dalam menghadapi realitas semesta adalah dari mana alam ini berasal dan bagaimana alam ini menjadi ada. Berbagai gagasan spekulatif telah banyak diungkapkan oleh para filosof dalam memecahkan problem tersebut, terutama untuk melacak basis ontologi eksistensi, baik yang bersifat material maupun bilangan. ${ }^{1}$ Pada prinsipnya, mereka beranggapan bahwa substansi material haruslah satu (monisme). Puncak dari upaya tersebut adalah ide tentang Penyebab Pertama (First Cause atau Causa Prima) gagasan Aristoteles. Pandangan tersebut menjadi pijakan dasar (standpoint) bagi para filosof generasi berikutnya dalam merumuskan gagasan mereka tentang proses kejadian atau penciptaan alam. ${ }^{2}$ Namun ide tentang Penyebab Pertama yang tunggal telah mendatangkan persoalan mendasar tentang bagaimana hubungannya dengan pluralitas alam. ${ }^{3}$ Untuk menjembatani kesenjangan

1Dalam tradisi filsafat alam upaya melacak substansi tunggal material sebagai asal-usul alam menandai lahirnya filsafat. Para filusuf awal seperti Thales beranggapan bahwa substansi alam adalah air, Anaximines udara, Heraklitos api, Pytagoras bilangan, sementara Demokritos atom. Bertens, Sejarah Filsafat Yunani (Jakarta: Kanisius, 1975), h. 26. Abbas Mahmoud al-'Akkad, Ketuhanan, Sepanjang Ajaran Agama-agama dan Pemikiran Manusia (Jakarta: Bulan Bintang, 1972), h. 122. Bertrand Russel, History of Western Philosophy (Oxford: Alden Press, 1974), h. 49-59, 206.

${ }^{2}$ Aristoteles sebagai figur yang secara umum diakui memiliki pengaruh terbesar bagi pemikiran Islam, sementara konsep mistisisme dalam Islam dibangun atas literatur Neo-Platonik. Lihat Giorgio DE. Santillana, "Preface" dalam Seyyed Hossein Nasr, Science and Civilization in Islam (Cambridge: Harvard University Press, 1968), h. 7-10. W. Montgomery Watt, Islamic Philosophy and theology (Endinburg: Endinburg University Press, 1972), h. 94-97. Mustafa Majid al-Azraq, Tamhïd li Tārīkh al-Fasafat alIslāmiyyah (Kairo: Lajnah al-Ta'lif wa al-Tarjamat wa al-Nasyr, 1379/1959), h. 38-39. Syahrastani, alMilal wa al-Nihal (Mesir: Dar al-Misriyah, t.th.), h. 253. Ibn Khaldun, Muqaddimah (Beirut: Dar al-Fikr, 1981), h. 514. Ibrahim Madkour, Fì al-Fasafat al-Islāmiyyah Manhaj wa Tatbīquh, jilid I (Kairo: Dār alMa'ārif, 1981), h. 514. Fazlur Rahman. Islam (Chicago: Chicago University Press, 1979), h. 119. Syed Ameer Ali, The Spirit of Islam (India: Idarah al-Adabiyah al-Delli, t.th.), h. 426-427. G.E. Von Grunebaum, Classical Islam, a History 600-1258 (London: George Allen \& Unwin Ltd, 1970), h. 133. Poerwantoro dkk, Seluk Beluk Filsafat Islam (Bandung: Remaja Rosdakarya, 1994), h. 115-116.

${ }^{3}$ Masalah hubungan Penyebab Pertama (Yang Tunggal) dengan alam manifetasi yang jamak dan relatif menjadi masalah abadi filsafat. P.J. Zoetmulder, Pantheisme En Monisme de Javaansche Soeloeklitteratuur, terj. Dick Hartono, Manunggaling Kawula Gusti: Panteisme dan Monisme dalam Sastra Suluk 
tersebut, sejak tradisi kuno sampai pemikir belakangan, menjadikan realitas cahaya sebagai dasar dalam menjelaskan hubungan tersebut, sekaligus sebagai basis ontologis, ${ }^{4}$ terutama di kalangan filosof Muslim.

Meskipun sains dibangun atas dasar pemahaman rasionalitas terhadap tatanan semesta melalui proses observasi, penyelidikan (inquiry), dan pembuktian yang mengarah pada teoritisasi dalam bingkai metodologi ilmiah. ${ }^{5}$ Dengan konsekuensi mendasar bahwa sains tidak ada kaitannya dengan ide penciptaan, fenomena alam adalah kontinuitas dari proses menjadi sesuai dengan hukum yang berlaku bagi segala aktivitas semesta. Meskipun demikian, pencarian sains modern terhadap basis realitas berujung pada kesamaan prinsip sebagaimana dalam tradisi mistisisme agama-agama yang bersifat perennis. Realitas paradoks dalam hukum transmisi "cahaya" memainkan peran penting dalam mendapatkan pengetahuan aktual dan proses pemikiran berkelanjutan. ${ }^{6}$ Dalam sains modern memandang bahwa basis realitas alam adalah manifestasi gelombang yang mengandung situasi paradoks (energimateri) dari hubungan alam ganda dalam bentuk radiasi. Fenomena gelombang yang menjadi basis teori sains modern telah merubah cara pandang terhadap alam secara mendasar. Equivalensi antara materi dan energi dalam teori relativitas dan asas ketidakpastian dalam teori kuantum, alam tidak lagi dipandang sebagai sesuatu yang deterministik, mekanik, dan eksak, ${ }^{7}$ tetapi

Jawa (Jakarta:Gramedia, 1990), h. 1. Bertrand Russel, History of Western, h. 13. Lorens Bagus, Metafisika (Cet I; Jakarta: Gramedia, 1991), h. 3-4. C.A. Qadir, Philosophy and Science in the Islamic World, terj. Hasan Basri, Filsafat dan Ilmu Pengetahuan dalam Islam (Jakarta: Yayasan Obor Indonesia, 1991), h. 10.

${ }^{4}$ H.P. Blavatsky, Isis Unveiled, A Master-Key to the Mysteries of Ancient and Modern Science and Theology, jilid I (California: The Theoshopical Publishing Company Point Lama, 1906), h. 299-302.

${ }^{5}$ Francis Bacon (1642-1626) telah sukses metetakkan landasan dasar bagi metode ilmiah dengan kerangka impirisme induktif. Lihat Poedjawijatna, Pembimbing ke Arah Alam Filasafat (Jakarta: Rineka, 1990), h. 104. Yūsuf Karam, Tārīkh al-Falsafat al-Hadīthah (Mesir: Dar al-Ma'ārif, t.th.), h. 48-50. Untuk kerangka metodologi ilmu pengetahuan dalam perspektif yang lebih luas dapat dilihat dalam Jujun Suria S. Sumantri, Ilmu dalam Sebuah Prospektif, Sebuah Karangan Hakekat Ilmu (Jakarta: Yayasan Obor Indonesia: 1994); Filsafat Ilmu Sebuah Pengantar Populer (Jakarta: Sinar Harapan, 1995); A.F. Chalmers, Apa itu Yang dinamakan Ilmu? Suatu Penilaian Tentang Watak dan Status Ilmu Serta Metodenya (Jakarta: Driyakara, t.th.). h. 42.

${ }^{6}$ Albert Einstein, Relativity, the Special and the General Theory (New York: Bonanza Books, 1952),

7John Gribbin, In the Beginning: The Birth of the Living Universe (Boston: Little, Brown and Company, 1993), h. 19. Determinisme alam dalam pandangan fisika klasik dipelopori oleh Isaac Newton (1642-1727), dia telah memberikan landasan dasar teori metematis, eksak, dan mekanik dan konsisten tentang alam. Dinamika Newton telah diterima sebagai kerangka nalar dasar bagi pemahaman yang mendalam tentang asas prilaku alam. Lihat Poedjawijatna, Pembimbing, h. 71; Yūsuf Karam, Tārìkh, h. 
secara mendasar alam berperilaku relatif dan tidak pasti. ${ }^{8}$ Implikasi mendasar dari teori relativitas dan asas ketidakpastian kuantum adalah adanya titik balik pandangan (shift paradigm) para ilmuan terhadap realitas alam. ${ }^{9}$ Isu penciptaan menjadi masalah fundamental dalam sains untuk melacak bagaimana alam ini menjadi. ${ }^{10}$

Ilustrasi di atas menunjukkan bahwa puncak pencarian basis ontologis semesta terdapat konvergensi antara agama dan sains yang menempatkan "prinsip cahaya" sebagai basis teorinya. Namun demikian, masing-masing masih menyisakan masalah mendasar. Dalam agama belum dapat menjelaskan bagaimana proses terjadinya alam fisik dari cahaya metafisik. Sebaliknya dalam sains belum dapat menjelaskan dari mana asal-usul cahaya (energi) sebelum peristiwa big bang. Landasan normatif yang menyebutkan secara eksplisit realitas cahaya sebagai basis ontologi semesta terdapat dalam hadis yaitu "Cahaya Muhammad" dengan merujuk pada hadis tentang "tanpa Muhammad maka realitas alam tidak akan tercipta". Dengan mengesampingkan sementara berbagai penafsiran terhadap aspek historisitas Muhammad dan aspek avatara

145. Konsekuensi teologis dari pandangan alam determisme alam ala Newton menjadi perdebatan serius. Lihat Libnis and Clarke, "Controversi on Time and Creation" dalam Baruch (USA: Pretice Hill Inc, 1974), h. 436-438. Secara Filosofis bangunan logis metode ilmu pengetahuan didukung oleh Rene Descartes (1596-1650). Lihat P. Hartono Hadi, Epistemologi Filsafat Pengetahuan (Yogyakarta: Kanisius, 1994), h. 28-34; secara sistematis metode pemikirannya dapat dilihat Rene Descartes, "Two Traditions" dalam Rendall Buchler dan Shirk (ed.), Reading Philosophy (New York: Barnies \& Nober Inc, 1950), h. 18-29.

${ }^{8}$ Einstein menawarkan prinsip relativitas tentang konsep ruang waktu yang terinspirasi laju kecepatan cahaya yang akan merombak seluruh paradigma tentang absoluditas ruang-waktu yang hukumnya dapat berlaku bagi seluruh tatanan realitas. Lihat Joko Siswanto, Kosmologi Einstein (Yogyakarta: Tiara Wacana, 1996), h. 57-60. Untuk kedua postulat teori relativitas Einstein lihat Keneth S. Krane, Fisika Modern (Jakarta: UI Press, 1992), h. 31-32 dan 638-639.

${ }^{9}$ Dapat dilihat dari berbagai karya berikut: S. Toulmin, The Return to Cosmology, Postmodern Science and Theologi of Science (London: Unwin Paperback, 1989). S.L. Jaki, Cosmos and Creator (Endinburg: Endinburg University Press, 1980). Pengarang yang sama, God and the Cosmologist (Endinburg: Endinburg University Press, 1989). Paul Devies, God and New Physic (New York: Simon \& Schuster, 1969). Pengarang yang sama, Mind of God (New York: Touchstone, 1983).

${ }^{10}$ No scientific problem is more fundamental or more daunting than the puzzle of how the universe came into being. Could this have happened without any supernatural input? Quantum physics seems to provide a loophole to the age-old assumption that 'you can't get something from nothing.' Physicists are now talking about the 'self-creating universe': a cosmos that erupts into existence spontaneously, much as a subnuclear particle sometimes pops out of nowhere in certain high energy processes. The question of whether the details of this theory are right or wrong is not so very important. What matters is that it is now possible to conceive of a scientific explanation for all of creation. Has modern physics abolished God altogether. . .? Lihat Paul Davis, God and the New Physics (New York: Simon and Schuster, 1983), h. 215. 
Muhammad, hadis di atas secara tegas menyebutkan bahwa realitas semesta bersumbar dari cahaya.

\section{B. Landasan Teori}

“Ontologi” berasal dari kata ontology yang berarti gagasan tentang kejadian yang paling murni dari ilmu pengetahuan yang menginvestigasi terhadap alam semesta. Ontologi berasal dari bahasa Yunani on atau ontos yang berarti ada (being) dan kata logos yang berarti ilmu (logic), atau ilmu tentang ada sebagaimana adanya secara integral dengan segala aspeknya. ${ }^{11}$ Secara garis besar, ontologi dipahami sebagai teori tentang "ada" dan keberadaannya, ${ }^{12}$ sebagai bagian dari metafisika. ${ }^{13}$ Istilah tersebut pertama kali digunakan oleh Rudolf Geoclenius (1636), ${ }^{14}$ bagi Abraham Calovius, ontologi digunakan sebagai bagian dari ranah metafisika yang menyangkut kosmologi dan psikologi. Sementara I. Kant menganggap ontologi sebagai ilmu tentang Tuhan dan alam yang menyangkut segalanya (once for all).15 Dia mengkategorikan ontologi sebagai analitik transendental, pengetahuan apriori tentang yang ada secara umum dalam kerangka doktrin sistemik (hukum kausalitas) yang hanya dapat dianalisis dengan pengetahuan murni. ${ }^{16}$ Senada dengan I. Kant, Husserl meng-

11Dagobert D. Runes, dictionary of Philosophy (New Jersy: Little Adam \& Co, 1976), h. 219.

${ }^{12}$ A. Dardiri, Humaniora, Filsafat dan Logika (Jakarta: Rajawali Press, 1986), h.17.

${ }^{13}$ Secara sistemik dapat dilihat dalam Lorens Bagus, Metafisika (Jakarta: Gramedia, 1991). Ontology is the theory of being qua being or the study of the nature of existence and being in the abstract" or " the science of being and universal order" This is the level of metaphysical categories. J.B. Sylies (ed.), Oxford Dictionary, h. 765.

${ }^{14}$ The Latin term ontologia was felicitously invented in 1613, independently, by two German philosophers, Rudolf Gockel (Goclenius) in his Lexicon Philosophicum and Jacob Lorhard (Lorhardus), in his Theatrum Philosophicum, but first entered general circulation when popularized by Christian Wolff in his Latin writings, especially his Philosophia Prima sive Ontologia of 1730. The first known English use of the term "ontology" is 1720. (1) General as distinct from special metaphysics. (2) More limitedly, the list or table of basic kinds of entities. (3) Attributively, as in "Quine's ontology," the basic kinds of entities assumed by a given philosopher. (4) In Ingarden's philosophy, the study of all possible general arrangements of the world, by comparison with metaphysics which concerns only what actually exists". Lihat Robin Le Poidevin Robin (ed. etal). The Routledge Companion to Metaphysics (New York: Routledge 2009), h. 590-591.

${ }_{15}^{15}$ Paul Edward (ed.), The Encyclopedia of Philosophy, V (New york: Macmillan Publishing Co. Inc The Free Press, 1972), h. 542.

16 "Its principles are merely principles e of the exposition of appearances, and the proud name of an ontology, which presumes to offer synthetic a priori cognition of things in general in a systematic doctrine (e.g., the principle of causality), must give way to the modest one of a mere analytic of the pure understanding." Lihat Immanuel Kant, Critique of Pure Reason (Cambridge: Cambridge University Press, 1998), h. 358-359. 
kategorikan sebagai ilmu pengetahuan apriori tentang objek secara general yang berkaitan dengan makna dalam pengertian umum. Secara umum, teori tentang objek adalah pengetahuan apriori tentang oyek secara menyeluruh baik berkaitan dengan eksistensi dan non-eksistensi.

"The theory of objects is an a priori science which concerns the whole of what is given, existent or nonexistent. Existent objects must be distinguished from subsistent or ideal objects, such as identity, diversity, or number. Existence and subsistence are the two forms of being, whereas the 'pure object' considered in the theory of objects is beyond being and nonbeing" 17

Sebagai cabang filsafat, ontologi bertujuan menginfestigasi dan mengabstraksikan hakikat realitas peripurna yang bersifat tunggal, absolud dan abadi.18 Dalam artikel ini, ontologi berorientasi dan terfokus pada persoalan kosmologi secara integral. Sebuah upaya untuk melacak muasal ekesistensi semesta sebagai yang "ada" dan tidak terlepas dari realitas Pencipta.

Landasan normatif penciptaan semesta (langit dan bumi) dalam al-Qur'an, mayoritas lebih ditujukan kepada fungsi dan tujuan bagi manusia sebagai sebuah "pertanda". ${ }^{19}$ Sementara tentang bagaimana proses penciptaan alam, alQur'an hanya menyebutkan tergulungnya langit sebagai tanda bagi berakhirnya riwayat alam semesta sebagaimana pada awalnya. ${ }^{20}$ Secara spesifik al-Qur'an tidak menyebutkan basis ontologi alam, kecuali realitas yang bersifat parsial, seperti muasal penciptaan iblis, jin, ${ }^{21}$ dan manusia. ${ }^{22}$ Sementara dalam hadis

17Marvin Farber, The Foundation of Phenomenology. Edmund Husserl and the Quest for a Rigorous Science of Philosophy (Cambridge: Harvard University Press, 1943), h. 205-206. according to Husserl, its object is the study of the genera of being, the leading regional concepts, i.e., the categories; its true method is the eidetic reduction coupled with the method of categorial intuition. The phenomenological ontology is divided into two: (I) Formal, and (II) Regional, or Material, Ontologies. Lihat Barry Smith, Hans Burkhardt (eds.), Handbook of Metaphysics and Ontology (Munich: Philosophia Verlag, 1991), h. 640 .

${ }^{18}$ Suparlan Suhartono, Filsafat Ilmu Pengetahuan, Persoalan Eksisitensi dan Hakikat Ilmu Pengetahuan (Yogyakarta: Ar-Ruzz Media, 2008), h. 112. (45): 4.

${ }^{19}$ QS. al-Baqarah (2): 164; Āli ‘Imrān (3): 190-191; al-Kahfi (18): 51; al-Furqān (25): 45; al-Jās|iyah

${ }^{20}$ QS. al-Anbiyā' (21): 104.

${ }^{21}$ Baik iblis maupun jin sama-sama berasal dari api. QS. al-Kahfi (18): 50; Al-A'raf (7):12; al-Hijr (15): 27; al-Rahman (55): 15;

${ }^{22}$ QS. al-Sajdah (32): 7; al-Hijr (15): 26,28,29; Shad (38):71; al-An'am (6):2; al-Mukminun (23)1214; al-Rahman (55):4. Secara akumulatif, bahan-bahan tersebut terangkum dalam al- hadis yang menyebutkan bahwa malaikat tercipta dari cahaya, iblis dan jin dari api, sementara manusia dari tanah. Lihat Muslim, al-Jāmi' al-Ṣahịh, jilid xvi (Beirut: Dār al-Fikr, t.th.), h. 123, Ahmad ibn hanbal, Musnad Ahmad ibn hanbal (Beirut Dāंr al-Kutub al-'Arabiy, 1979), hadis no. 24668... Ibnu Hibban, no. 6155. 
disebutkan bahwa ciptaan adalah manifestasi kasih sayang (rahmat) Allah, ${ }^{23}$ satu berbanding sembilan puluh sembilan. ${ }^{24}$ Terdapat hadis tentang keberadaan Tuhan sebelum mencipta, yaitu di atas ' $a m a$ ', kemudian Dia menciptakan Arsy di atas air, ${ }^{25}$ selanjutnya dicipta langit dan bumi, ${ }^{26}$ sebagai Khazanah Tersembunyi, Dia mencipta agar diketahui. ${ }^{27}$ Selain bersifat teknis secara eksplisit terdapat hadis yang menyebut tentang muasal penciptaan. Hadis yang menyinggung tentang basis ontologi yaitu hadis yang berkaitan dengan realita penciptaan pertama yaitu al-Qalam (Pena) ${ }^{28}$ dan Lawh al-Mahfüz (Lembaran Terjaga), sementara yang langsung menyentuh persoalan basis ontologis adalah tentang Cayaha Muhammmad (Nür Muhammmad). ${ }^{29}$ Dengan merujuk pada hadis tentang "Adam tercipta dari Nur Muhammad"30 dan hadis yang menyebutkan bahwa tanpa "Muhammad maka realitas alam tidak akan tercipta". Berbagai istilah dalam hadis atas pada dasarnya merujuk pada realitas tunggal yitu wujud bukan zat.

Secara universal, realitas cahaya menjadi alat paling efektif dalam menjelaskan realitas semesta beserta hukum yang berlaku termasuk dalam melacak basis ontologi semesta. Prinsip "antinomik" dalam realitas "cahaya" equivalen dengan esoterisme "alam antara" yang bersifat maya menjadi kunci dasar dalam filsafat perennial. Dalam tradisi India, Budha identik dengan "Cahaya", "Kebijaksanaan", "Pengetahuan" atau intelek Tuhan sebagai manifestasi dari

${ }^{23} \mathrm{Abū}$ 'Abdillāh Muhammad ibn Isma'îl al-Bukhāriy, al-Jāmi' al-Ṣaḥịh, jilid III-IV (Beirut: Dār alKutub al-'Ilmiyyah, 1412 H/1992 M), h. 409 dalam kitāb bada' al-khalq, selanjutnya lihat juga jilid VIIVIII dalam kitab tawhìd, h. 528 dan 534. Dengan redaksi yang berbeda, tetapi secara substansi sama dapat dilihat dalam Abū 'Isā Muhammad ibn 'Isā ibn Surah al- Tirmidhī, Sunan al-Tïmidhī, jilid III (Beirut: Dār al-Fikr, 1400 H/ 1980 M), h. 513; Muslim, al-Jāmi' al-Ṣaḥihh, jilid IV (Beirut: Dār al-Fikr, t.th.), h. 2107. Hadis ini terdapat dalam bab kelapangan rahmat Allah; Abdillah ibn Yazid al-Qazwiniy ibn Mājah, Sunan Ibn Mãjah, jilid II (Beirut: Dār al-Fikr, t.th.), h. 1435, disebutkan dalam bab zuhud; Ahmad ibn hanbal, Musnad Ahmad ibn Hanbal, jilid II (Beirut Dār al-Kutub al-'Arabiy, 1979), h. 242, dan disebutkan dalam banyak tempat oleh imam Ahmad; al-Nasāi, Sunan al-Nasāí, jilid IV (Beirut: Dār alFikr, 1348 H / 1930 M), h. 237, khususnya dalam bab sifat-sifat Allah.

${ }^{24}$ Ismaîl al-Bukhāriy, al-Jāmi' al-Ṣahịh., jilid IV-V, h. 234 dalam bab al-Riqāq

25al-Tirmidhī, Sunan, jilid V, h. 234. Ahmad ibn Ḥanbal, Musnad., jilid II, h. 313 dan 501, dan jilid IV, h. 43

${ }^{26}$ Isma'il al-Bukhāriy, al-Jāmi'., jilid III-IV, h. 409.

27Jalal al-Dīn 'Abd al-Rahman Abu Bakr al-Suyutị, al-Durar al-Muntashirat fi al-Ahādīth alMashhūrah (Cet. II; Beirut: Dār al-Kutub al-'Ilmiyyah, 1988), h. 203.

28 al-Tirmidhī, Sunan, hadis no. 2155. Abu Daud, sunan, hadis no. 4700.

29 Jalāl al-Dīn al-Suyuṭi, Qut al-Mughtazi 'ala Jami' al- Tirmidhī, Juz. I, h.. 516.

30 Ibnu Sa’ad, al-Ṭabaqat al-Kubra, Maktabah Syamilah, Juz. I, h. 118. 
Adhi Budha (Supreme Wisdom), Esensi yang tak dapat diketahui. Budha menempati prinsip "maya", eksistensi antara bagi jalan menifestasi alam. ${ }^{31}$ Demikian halnya dalam tradisi Hindu, ParaBrahman adalah represantasi dari Ketersembunyian, Tanpa nama, Tak terkondisi, Sebab Absolut. Sementara Brahman merupakan Eksistensi Diri (Self Existence) dalam prinsip "maya" dengan potensi gender (male-famale) secara emanatif akan melahirkan alam. ${ }^{32}$ Dengan skema yang lebih rumit, prinsip yang sama dapat dijumpai dalam kosmologi Yahudi yaitu dalam tradisi Kabbala, ketersembunyian absolut disebut dengan Ayin (Oya) atau Ain Shop-Ketidakberadaan (the No-Thing) - melampaui Kearifan yang tidak mungkin dijangkau oleh pengetahuan. Sementara cahaya disebut dengan Ain Shop Aur yang tidak bertentangan dengan kegelapan bersifat paradoksal antara kontraktif dan ekspansif sekaligus sebagi simbol energi sentripetal dan sentrifugal penciptaan. ${ }^{33}$ Hal yang sama juga dapat ditemukan dalam tradisi kosmologi China, melalui potensi yin dan yang, Tao akan melahirkan segala sesuatu (seluruh eksistensi). ${ }^{34}$ Secara mendasar, prinsip maya merupakan akar bagi aksi kreatif Keagungan Energi Tunggal (One Supreme Energi) atau Kekuasaan Tuhan (Divine Powers) sebagai Pencipta. Secara universal prinsip yang sama dapat dilacak dalam tradisi mistisisme Mesir kuno, Zoroaster di Persia, Babilonia, dan Yunani dengan Hermes sebagai figur utamanya. ${ }^{35}$ Universalitas prinsip dasar ontologi menjadi pengetahuan yang bersifat abadi sebagai pesoalan pokok dalam filsafat perennial.

Senada dengan tradisi esoterisme agama-agama, melalui prinsip "antinomi" dalam realitas cahaya, sains monemukan formulasi yang mapan dalam menjelaskan realitas semesta beserta hukum yang berlaku, serta dapat menelusuri muasalnya. Equivalensi antara materi dan energi melalui prinsip "cahaya" $\left(E=m c^{2}\right)$ dalam teori relavitas khusus (special theory of relativity), ${ }^{36}$ xviii-xx.

${ }^{31}$ H.P. Blavatsky, The Secret Doctrine, jilid I (Madras: The Theosophical Publishing House, 1987), h.

32Ibid, h. 7-8.

33J.F.C. Fuller, The Secret Wisdom of the Qabalah: A Study in Jewish Mistical Thought (ttp: t.th.), h. 22.

${ }^{34}$ Sachiko Murata, The Tao of Islam (Bandung: Mizan, 1992), h. 29.

35J.F.C. Fuller, The Secret Wisdom, h. 8 dan 12.

36Untuk menselaraskan antara teori dan eksperimen, bagi Einstein hanya dengan merevisi ide fundamental tentang ruang dan waktu. Dengan prinsip "cahaya" (energi-materi), ruang-waktu menjadi satu kesatuan yang relatif, dinamis, dan subjektif. Peter Gabriel Bergmann, Introduction to Theory of Relativity (Tokyo: Japan Publication Trading, Co. Ltd, 1961), h. xiv, 92-93. Sementara gravitasi ditentukan oleh partikel-partikel penyusun alam yang berasal dari medan-medan singularitas, sehingga 
mengisyaratkan bahwa materi apa pun jika bergerak dengan kecepatan cahaya, maka akan manjadi energi yang tidak lain adalah cahaya itu sendiri. ${ }^{37}$ Prinsip cahaya dalam teori relivitas telah membuka jalan bagi Heisenberg untuk menformulasikan asas ketidakpastian (uncertainly principle) dalam mekanika kuantum. ${ }^{38}$ Kedua teori di atas merupakan puncak teori sains yang menunjukkan bahwa perilaku alam mengikuti teori relativitas dan ketidakpastian. Isu penciptaan menjadi masalah fundamental dalam sains untuk melacak bagaimana alam ini menjadi. Sebagaimana gagasan Stephen Hawking yang menggabungkan teori relativitas dengan asas ketidakpastian menjadi teori kuantum gravitas, dia mengembangkan teori Gamow tentang big bang (dentuman besar) dari sebuah titik singularitas sebagai asal-usul alam. ${ }^{39}$ Teori big bang sebenarnya sebagai hasil antitesis terhadap fenomena supernova pada proses peluruhan bintang yang berujung pada titik singularitas.

Meskipun para filosof menggunakan mediasi cahaya menformulasikan gagasan mereka tentang penciptaan, akan tetapi teoritisasi cahaya dalam penelitian mereka masih sangat terbatas. Secara filosofis, teori dasar dari antinomi cahaya adalah teori mediumistik gagasan Aristoteles, ${ }^{40}$ pengetahuan murni gagasan I. Kant, ${ }^{41}$ dan objek murni E. Hussrel. ${ }^{42}$ Dalam filsafat Islam, teori yang dikenal adalah "teori warna" dari gagasan Aristoteles yang diikuti oleh al-

akan membentuk lengkung ruang-waktu. Peter Gabriel Bergmann, Introduction to Theory of Relativity, h. 241.

${ }^{37}$ Karena kecepatan cahaya memiliki batas waktu tertentu, satu meter ditempuh 0,000000003335640952 detik, jika dibulat sama dengan 3×10-9 meter per-detik. Stephen Hawking, Brief Hitory of Time, terj. A. Hadyana Pudjaatmaka, Riwayat Sang Kala, Dari Dentuman Besar hingga Lubang Hitam (Jakarta: Pustaka Utama Grafiti, 1993), h. 25.

${ }^{38}$ Cahaya, energi radiasi, dan gelombang tidak keluar secara terus-menerus, tetapi berupa paketpaket energi (quantum). Dalam teori kuantum, orang tidak akan mampu menentukan posisi dan saat momentum partikel secara tepat. Dalam sub atom, materi lebih menunjukkan "tendensi-tendensi untuk ada" dan "menjadi". Lihat ibid, h. 70-71; Stephen Hawking, A Brief Hitory h. 61-62.

${ }^{39}$ Lihat Stephen Hawking, A Brief Hitory of Time. Karya lain, Black Holes and Baby Universes, \& Other Essays, terj. Alex Tri Kuntjoro Widodo, Lubang Hitam dan Jagat Bayi dan Esai-esai lain (Jakarta: Gramedia, 1995). Ketty Ferguson, Quest for A Theory of Univers, terj. A. Hadyana Pudjaatmaka, Mencari Teori Segala Hal (Jakarta: Pustaka Utama Grafiti, 1995). Secara teoritik dapat dilihat dalam Kenneth S, Krane, Modern Physic, terj. Hans J. Wospakrik, Fisika Modern (Jakarta: UI Press, 1992).

${ }^{40}$ Abdi O. Shuriye,"Islamic Position on Physic with Reference to Ibn Al-Haytam" dalam International Journal of Applied Science and Technology, Vol. 1 No. 2; April 2011. Dapat di akses dalam www.ijastnet.com. 358-359.

41Immanuel Kant, Critique of Pure Reason (Cambridge: Cambridge University Press, 1998), h.

${ }^{42}$ Marvin Farber, The Foundation of Phenomenology. Edmund Husserl and the Quest for a Rigorous Science of Philosophy (Cambridge: Harvard University Press, 1943), h. 205-206 
Farabi, Ibnu Sina, Ibn Haytam, Ibnu Bajjah, dan Muhammad Karīm-Khan Kirmāni.43 Pada dasarnya teori penciptaan yang digunakan para filosof lebih menekankan pada teori umum emanasi. Untuk memformulasikan teori "antinomi" cahaya, QS. al-Nūr (24): 35 dapat dijadikan pijakan teori. Ayat tersebut secara tegas menyebutkan realitas "Cahaya" merujuk pada identitas Sang Pencipta (Allah) yang berkaitan langsung dengan realitas semesta (langit dan bumi). Formulasi teori "antinomi" cahaya dari QS. al-Nūr (24): 35 dapat dirinci sebagai berikut:

1. Perumpamaan Allah sebagai Cahaya adalah seperti Miskāt (lubang yang tak tembus cahaya). Dalam hadis disebut dengan Khazanah Tersembunyi (Kanzan Makhfiyyan). Sementara dalam filsafat disebut dengan Kehampaan, AdhiBudha, ParaBrahman, Ibnu 'Arabi menyebut dengan ke-Esaan Zat (Ahadiyah), Esensi Tuhan atau Non-Wujud dalam istilah F. Schuon. Pada posisi ini tidak dapat dijangkau oleh pengetahuan maupun ma'rifat setinggi apapun. Adapun dalam sains, disebut dengan kevakuman dalam teori medan kuantum dan titik singularitas, dimana tidak ada satu teoripun dalam sains yang dapat diterapkan.

2. Pelita sebagai sumber cahaya atau sumber eksistensi, dalam hadis disebut dengan Pencipta (khalaqtu), maka dalam filsafat disebut dengan Eksistensi (Wujūd dan bukan Zat) Tuhan, Brahman, Budha sebagai menifestasi pertama yang bersifat potensial. Tidak di Barat dan Timur merupakan simbol dua kutub berlawanan yang masih menyatu, sehingga bersifat "antinomik" (yinyang, male-female, nama-nama dan sifat-sifat Tuhan yang berlawanan) yang tidak dapat dibedakan, Ibnu 'Arabi menyebut Ketunggalan (wahidiyah). Dalam sains disebut dengan medan kuantum yang dapat memanifestasikan materi dan anti materi atau partikel dan energi dalam waktu bersamaan.

3. Cahaya di atas cahaya (berlapis-lapis) adalah gambaran herarki eksistensi dan Eksistensi Allah berada di puncak sebagai sumber segala eksistensi. Dalam sains disebut dengan aksi kreatif yang tidak pernah berhenti. Sifat cahaya yang meliputi seluruh ruang mengindikasikan keserbamencakupan pengetahuan Tuhan.

4. Hubungan prinsip cahaya dalam filsafat dan sains adalah berkaitan dengan kesamaan sifat "antinomik" cahaya. Meskipun hermeneutika cahaya dalam

${ }^{43}$ Henry Corbin, Temple, h. 3. 
filsafat bersifat simbolik yang dibangun berdasarkan pada realitas spiritual yang intergral.

Secara garis besar teori "Antinomi" dalam prinsip cahaya sebagai basis ontologi realitas adalah sebagai berikut:

\begin{tabular}{|c|c|}
\hline Agama dan Filsafat & Ilmu Pengetahuan (Sains) \\
\hline \multicolumn{2}{|c|}{ Paradoks realitas cahaya yang bersifat tunggal (antinomi) } \\
\hline $\begin{array}{l}\text { - Tidak di barat dan di timur } \\
\text { - Male - Female } \\
\text { - Nama-nama dan identitas Tuhan } \\
\text { yang berlawanan } \\
\text { - Yin Yang }\end{array}$ & $\begin{array}{l}\text { - Kesetaraan materi dan energi } \\
\text { - Gerak denga kecepatam maksimum } \\
\text { sekaligus diam } \\
\text { - Ada dan tidak ada sekaligus, } \\
\text { gerak sekaligus diam } \\
\text { - Aksi kreatif }\end{array}$ \\
\hline \multicolumn{2}{|c|}{ Realitas (wujud) } \\
\hline $\begin{array}{l}\text { - Nūr Muhammad } \\
\text { - Wujud (bukan Non Wujud atau Zat) } \\
\text { - Budha } \\
\text { - Brahman } \\
\text { - al-A'yān al-Thābitah }\end{array}$ & $\begin{array}{l}\text { - Cahaya } \\
\text { - Partikel } \\
\text { - Medan Quantum }\end{array}$ \\
\hline
\end{tabular}

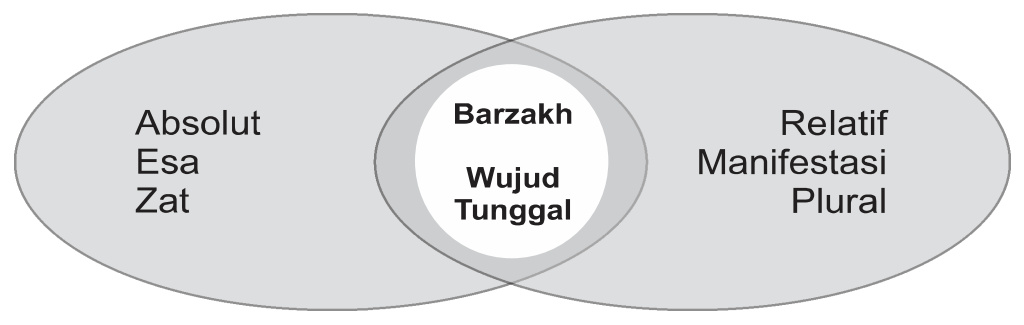

Berdasarkan sifat "antinomik" cahaya baik dalam filsafat maupun sains, merupakan bukti terdapatnya konvergensi agama dan sains dalam teori tersebut". Sifat "antinomi" melalui dasar "energi" dari prinsip cahaya dapat digunakan sebagai "sebab" dalam skema proses penciptaan maupun kejadian alam. Pola-pola realitas (sistem kosmos) menghadirkan tatanan tunggal yang 
teratur dalam hukum alam. ${ }^{44}$ Sebuah gambaran yang sama dalam kosmologi perennis, prinsip kosmologi dengan karakter kesatuan dan gradasi penciptaan yang berawal dari Yang Satu. Pola dasar pencaran (illuminasi) secara langsung dihubungkan pada bentuk-bentuk natural sebagai cermin manifestasi kreasi diri Tuhan. Untuk menguji sejauh mana validitas teori ini, penulis akan berusaha membuktikan dengan argumentasi-argumentasi yang logis dan dengan dukungan data-data yang dapat dianggap representatif.

Konvergensi berakar dari kata converge yang berarti bertemu, berkumpul, dan berjumpa, convergence berarti tindakan bertemu atau berkumpul.45 Secara bahasa mangandung pengertian sebuah gerak yang mengarah pada kesatuan (moving toward union or uniformity) atau gerak yang memiliki kesamaan karakter yang dapat diasosiasikan melalui kesamaan kebiasaan atau lingkungan. ${ }^{46}$ Dari aspek teknologi, konvergensi berarti kombinasi dari atau lebih teknologi dalam satu perangkat. ${ }^{47}$ Fenomena phonsel yang dapat merangkum berbagai hasil teknologi sebelumnya (telephone, TV, radio, kamera, perangkat game dan lan sebagainya), adalah contoh dari konvergensi dalam bidang teknologi.

Sementara titik temu antara agama dan sains lebih banyak menggunakan istilah integrasi. Berangkat dari ungkapan Einstein: "Science without religion is lame, religion without science is blind" (sains tanpa agama pincang, agama tanpa sains adalah buta). ${ }^{48}$ Adapun ide integrasi keduanya diungkapkan oleh I. G. Barbour, yaitu bahwa integrasi dapat dilakukan melalui pendekatan teologis (nature theology dalam sains atau theology of nature dalam agama) dalam bingkai paradigma filsafat yaitu filsafat proses. ${ }^{49}$ Proses tersebut Pendekatan ini

${ }^{44}$ J.S. Mill mengakui bahwa keserasihan alam secara spirit dapat mengantarkan manusia untuk mengetahui tata kerja Tuhan sebagai manifestasi kehendak-Nya. John Struart Mill, " Nature" dalam Randall Buchler dan Shirk (ed.), Reading Philosophy (New York: Barneis \& Nober INC, 1950), h. 53. h. 145.

${ }^{45}$ John M. Echols dan Hassan Shadily, Kamus Inggris Indonesia cet. xix (Jakarta: Gramedia, 1993),

46http://www.merriam-webster.com/dictionary/convergence

${ }^{47} \mathrm{http}: / /$ whatis.techtarget.com/definition/convergence

${ }^{48}$ Statemen ini pertama kali dituangkan oleh Einstein dalam artikelnya yang berjudul "Ideas and Opinions", yang terbitkan dalam edisi pertama: Princeton Theological Seminary, May 19, 1939, h. 41-49. Dipublikasikan dalam: "Out of My Later Years" (New York: Philosophical Library, 1950). Edisi kedua dalam: "Science, Philosophy and Religion, A Symposium", published by the Conference on Science, Philosophy and Religion in Their Relation to the Democratic Way of Life, Inc., New York, 1941. Diunduh dari web.http://einsteinandreligion.com/scienceandreligion.html

${ }^{49}$ Ian G. Barbour, When Science Meets Relegion: Enemies, Strangers, or Partuers?, terj. E.R. Muhammad, Juru Bicara Tuhan antara Sains dan Agama (Bandung: Mizan, 2002), h. 42. Baginya terdapat tipologi hubungan antara agama dan sains, konlik, masing-masing independen yang berarti 
bertujuan untuk membuktikan kebenaran-kebenaran agama dengan temuamtemuam dalam saians, terutama teori-teori sains mutakhir. Sementara dalam Islam lebih dikenal dengan upaya atau gerakan islamisasi sains. Sederet nama yang menjadi tokoh gerakan tersebut, Syed M. Naquib al-Attas, Seyyed Hossein Nossein Nasr, Isma'il al-Faruqi, dan Ziauddin Sardar. Al-Attas, kesemuanya masih sebatas bingkai epistemologi yang dibumbui dengan ranah metafisika. ${ }^{50}$ Dalam artikel ini, titik temu keduanya lebih bersifat substantif yang berkaitan dengan realitas semesta secara universal.

\section{Cahaya sebagai Basis Ontologi Semesta dalam Agama dan Sains}

Landasan utama dalam melacak basis ontologi semesta tidak dapat terlepas dari landasan utama Islam. Formulasi kesaksian (syahadat) dalam Islam. Pernyataan syahadat pertama menyebutkan tidak ada tuhan (realitas, yang mutlak, kebenaran) kecuali Allah (Realitas, Yang Mutlak, Kebenaran). Hal tersebut merupakan penegasan bahwa Allah sajalah yang dapat disebut riil sebagai satu-satunya wujud Kebenaran. Sedangkan eksistensi dunia dan realitas lainnnya adalah kepalsuan, meskipun pada levelnya sendiri adalah riil.51 Dengan demikian, bagian pertama dalam syahadat merupakan aspek batin Allah sebagai formulasi ketakterbandingan atau abstraksi (tanzih). Adapun pernyataan syahadat kedua menyebutkan bahwa Muhammad adalah utusan (rasūl) Allah. Realitas Muhammad adalah mewakili tataran realitas alam empiris, sementara kata utusan ( $r a s u ̄ l)$ berarti sebagai juru bicara, manifestasi, dan lambang Allah dalam tataran alam empiris. ${ }^{52}$ Dengan kata lain, menyadari syahadat kedua sama halnya menyadari sepenuhnya bahwa realitas alam tidak lain aspek lahir (zāhir) Allah sebagai menifestasi, karena tidak ada satu pun yang ada di luar Allah. Realitas alam tidak lain adalah berasal dari satu-satunya Realitas sebagai sumber dari segala yang wujud. Menyadari bagian kedua syahadat sama halnya

terpisah, dialog, dan integrasi. Lihat ibid, h. 44. Hal senada diungkapkan oleh J.F. Haught, bahwa terdapat beberapa pendekatan berkaitan hubungan antara agama dan sains, konflik, kontras, kontak dan konfirmasi. Lihat John F.Haught, Sccience and Religion: From Conflict to Conversation, terj. Fransiskus Borgias, Perjumpaan Sains dan Agama, dari Konflik ke Dialog (Bandung: Mizan, 2004), h. 1.

50Zainal Abidin Bagis (et al), Integrasi Ilmu dan Agama Interpretasi dan Aksi (Bandung: Mizan,2005), h. 24.

${ }^{51}$ Frithjof Schuon, Understanding Islam (London: Unwin Paperback, 1976), h. 1.

52Ibid, h. 5. 
menyaksikan Allah di mana-mana dan menyaksikan segala sesuatu dalam diri Allah. ${ }^{53}$ Formulasi dua syahadat dalam Islam memiliki aspek transendensi dan immanensi Tuhan sekaligus atau prinsip integratif dan derevatif yang berfungsi sebagai penegasan atas kepastian dan sebagai equlibrium dalam Islam. Dengan demikian, Islam menekankan aspek keseimbangan antara yang batin dan lahir, atau aspek tanzị̣ dan tashbịh sekaligus.

Makna "Cahaya Muhammad" sebagai basis ontologi realitas yang tercantum dalam hadis qudsi tidak sesederhana pemahaman dengan logika linier. Meskipun dari aspek eksternal hadis (sanad), ${ }^{54}$ hadis tersebut dikategorikan sebagai hadis lemah, namun dari aspek internal (matn) ${ }^{55}$ mengandung keabsahan substansi yang universal. Hampir semua tokoh perennialis Muslim menggunakan identitas Cahaya Muhammad Untuk menelusuri jejak muasal semesta melalui prinsip hukum Tuhan (sunnatullāh atau hukum alam). Meskipun terkesan bertentangan dengan hadis lain yang menyebutkan bahwa pertama kali tercipta adalah Lembaran Terjaga (Lawh al-Mahfüz), Pena (alQalam), dan Akal ('Aql). Berbagai istilah yang disebutkan dalam hadis tersebut tidak menyimpang dari prinsip pasang-pasangan sebagai hukum Allah. Caya Muhammad (Nūr al-Muḥammadiyyah) banyak diungkapkan para sufi-secara

${ }^{53}$ Dengan kata lain, formulasi dua kesaksian dapat diibaratkan sebagai dua pasangan realitas empiris dan non empis yang tak terbedakan (antinomik), menuju syhadat pertama lewat shalat, sementara kesaksian kedua melalui shalawat, keduanya memiliki akar yang sama (صي)

${ }^{54}$ Keabsahan hadis dari aspek eksternal lebih mempertimbangkan validitas jaringan transformasi yang melibatkan sejumlah informan (rijal). Terminologi șahīh (صحيح) yang berarti selamat dari penyakit dan bebas dari aib atau cacat. Lihat Ibn Faris, Maqāyis al-Lughah, juz III (Beirut: Dar al-Jalil, 1986), h. 281. Secara definisi hadis șahīh adalah:

$$
\begin{aligned}
& \text { الحديث الصحيح: فهو الحديث المسند، الذي يتصل إسناده بنقل العدل الضابط عن العدل الضابط } \\
& \text { إلى منتهاه، ولا يكون شإذا، ولا معللاً. }
\end{aligned}
$$

Abu Amr Usman bin Abd al-Rahman al-Ṣalāh, 'Ulüm al-Hadīth (Madinah: Al-Maktabat alIslāmiyyah, 1972), h. 10. Definisi yang lebih ringkas:

$$
\text { ما اتصل سنده بالعدل الضابطين من غيرشذوذولا علةز }
$$

2.

Al-Nawawi, al-Targhïb li al-Nawawi 'a Ușūl al-Hadīth (Kairo: Abd al-Rahman Muhammad, t.th..), h.

${ }^{55}$ Secara tegas Ibn Taimiyah menyebutkan bahwa standar keabsahan hadis adalah ketika tidak bertentang dengan al-Qur'an, sekalipun dha'if secara sanad. Ibn Taimiyyah, 'Ulum al-Hadis (Beirut: Dar al-Kutub al-'Ilmiyyah, 1985), h. 14 
khusus oleh al-jilli-digunakan untuk menjelelaskan eksistensi tertinggi sebagai sumber realitas. ${ }^{56}$ Cahaya adalah energi, energi tidak lain merupakan potensialitas bagi segala manifestasi. Cahaya Muhammad adalah potensi primordial dari pernyataan kesaksian kedua dalam Islam. Jika dalam hadis disebutkan bahwa penciptaan alam identik dengan luapan kasih (rahmat) Allah, ${ }^{57}$ di samping Allah telah mengdentifikasikan Diri sebagai al-Rạ̣mān, maka al-Qur'an menegaskan bahwa diutusnya Muhammad secara simbolik merupakan wujud pelimpahan rahmat bagi seleruh eksistensi.58 Melihat potensialitas primordial tersebut, hanya beliau satu-satu ciptaan yang diberi hak prerogatif untuk memberi syafaat dan berhak atas shalawat-yang bersifat transenden, vertikal dan ruhaniyah, karena Allah dan para malaikat (rūhaniyyah) memberikan shalawat-tetapi juga salam -yang bersifat imanen dan horisontal, karena salam untuk para nabi lain dan seluruh makhluk. Sebagai cahaya abadi, realitas Nur Muhammad merupakan asal dari segala realitas yang menempati alam perantara (barzakh) atau menempati fungsi Maya. ${ }^{59}$

Prinsip berpasangan dalam realitas Cahaya Muhammad tetap melekat, dimana cahaya Muhammad bertindak sebagai pena (al-Qalam) yang menjadi aksi kreatif (yang) dan perpasangan dengan Jibril yang bertindak sebagai lembaran terjaga (Lawh al-Mahfüz) sebagai aksi reseptif. Realitas lembaran dalam kategori al-Ghazali disebut dengan alam al-malakut. ${ }^{60}$ Secara simbolik pasangan tersebut dapat ditunjukkan oleh peristiwa mi'raj Muhammad, dimana Jibril tidak dapat mencapai apa yang dicapai oleh Muhammad. Cahaya Muhammad yang bertindak sebagai Pena yang memuat seluruh ide dari segala

${ }^{56}$ Ada beberapa istilah yang dipakai oleh Ibn 'Arabi dalam menjelaskan logos Muhammad: Realitas Muhammad (al-Haqiqqah al-Muhammadiyah), Realitas segala Realitas (Haqīqah al-Haqäliq), Ruh Muhammad, Intelek Pertama (al-'Aql al-Awal), Singgasana (al-Arsh), Ruh Maha Besar (al-Rüh alA'žam), Manusia Sempuna (al-Insān al-Kämil), Pena Yang Maha Tinggi, Lingkaran hidup (Falaq alHayat), sarana bagi setiap ciptaan (al-Haqq al-Makhlūq bihi), Materi Pertama (al-Hayula), Qutb, Hamba universal ('Abd al-Jāmi'). Affify, Filsafat Mistik, h. 99-100.

${ }^{57} \mathrm{Abu}$ Abdillah Isma'il al-Bukhari, al-Jami' al-Sahịh (Beirut Dar al-Kutub al-Ilmiyah, 1412/1992), jilid iv-v, h.234; Imam Muslim, Șahịh (Beirut: dar al-Fikr, t.th.), jilid iv, h. 105; Abu Abdillah ibn Yazid alQazwini Ibn Majah, Sunnah Ibn Majah (Beirut: Dar al-Fikr, tth.), jilid ii, h. 1435; Ahmad Ibn Hanbal, Musnad (Beirut: dar al-Kutub al-'Arabi, 1979), jilidv, h. 439.

${ }^{58}$ QS. al-Anbiya (21):107.

${ }^{59 ` A}$ Abd al-Qadir Muhmud, al-Falsafat al-Șüfiyat fi al-Islām; Mașadiruhā wa Makānatuhā fi al-Dīn wa '-Hayāt (Beirut: Dar al-Fikr al-'Arabi, 1966), h. 524-525.

${ }^{60} \mathrm{Abū}$ hamīd Muhammad ibn Muhammad al-Ghazāli, Ma'ārij al-Quds fi Madārij Ma'rifat al-Nafs, dieditoleh Muhy al-Din al0Kurdi (Kairo: Dār al-Ma’ārif, 1327), h. 19. 
pola dasar (al-a'yān al-thābitah), dalam sebuah Pena, seluruh gagasan yang beragam tidak akan dapat dibedakan. Demikian halnya segala ide dan gagasan yang masih berada dalam akal dan pikiran tidak akan pernah dapat diketahui dan masih bersifat tunggal sebelum dituangkan. Pena tak akan dapat berfungsi tanpa ada sebuah Lembaran, maka antara pena dan lembaran terjaga merupakan pasangan primordial. Seluruh rangkuman gagasan dalam pena akan dapat terbaca melalui goresan berupa karya dalam bentuk semesta. ${ }^{61}$ Sementara ide dalam akal tidak akan dimengerti sebelum dihembuskan melalui nafas (alRaḥmān) dalam bentuk firman.62 Dengan demikian, seluruh realitas ciptaan merupakan menifestasi pewahyuan abadi. Itulah jalan-jalan langit yang membentuk tenunan magis dan dapat ditemukan jejaknya dalam alam semesta yang dapat memberikan jawaban bagi intelek manusia untuk mengarungi samodera rahmat tak berujung yang dipenuhi berkah Ilahi.

Penggalian makna cahaya sebagai penjelas realitas semesta orisinil dalam tradisi Perjanjian Lama dan Baru, cahaya digunakan sebagai identifikasi Tuhan.63 Sementara dalam filsafat Islam digunakan untuk menjelaskan realitas alam non-empiris atau alam-antara sebagai perluasan dari gagasan Plato melalui Philo dan Plotinus ke dalam Abad Pertengahan.64 Penggalian makna cahaya sebagai analog bagi tujuan representasi alam ketuhanan dan agen kosmogonik banyak dikembangkan oleh para filosof Muslim. Teologi Aristoteles tentang

${ }^{61}$ Lihat QS. al-Qalam (68): 1

${ }^{62}$ Lihat QS. Yasin (36): 82.

63Tidak dapat dipungkiri bahwa sebelum Islam datang penganut Nasrani Nestorian di Syria dan Persia mendirikan pusat penerjemahan teks-teks Yunani ke dalam bahasa lokal. Persenyawaan antara doktrin agama, filsafat Yunani, dan sain menjadi basis isu penciptaan yang dominan. Lihat David Lindberg, The Beginings of Western Science: The European Scientific Tradition in Philosophical, Religious, and Institutional Context, 600 B.C. to A.D. 1450 (Chicago: Chicago University Press, 1992), h. 168. Lain halnya Nasr yang memiliki hipotesis sebaliknya: "One can no longer speak of Christian and Jewish philosophy and then refuse to accept the reality of Islamic philosophy". Seyyed Hossein Nasr, Islamic Philosophy From Its Origin to The Present, Philosophy in the Land of Prophecy (U.S.A: State University of New York Press, 2006), h, 36.atau simak statemen W.E. Caroll: "Although my remarks will have as their focus developments in the Christian Latin West, we need to remember that in the natural sciences and in philosophy the Latin West was heavily influenced by the work of Muslim and Jewish thinkers". Lihat William E. Carroll, God and Physics: From Hawking to Avicenna. http://www.muslimphilosophy. com/sina/art/gpa.doc, h.1.

${ }^{64}$ Filosof Muslim bahkan dapat malampaui pendahulunya:" In this characterization of the Supreme Being, al-Farabi goes well beyond Aristotle in the direction of Plato and Plotinus, and formulates in the process the nearest thing to the ontological argument". Lihat Majid Fakhry, al-Farabi Founder of Islamic Neoplatonism, His Life, Works, and Influence (Oxford: Oneworld, 2002), h. 47. 
Penyebab Pertama atau Esa disebut dengan Cahaya Pertama atau Cahaya Segala Cahaya oleh para filosuf Muslim diidentikkan dengan identitas dan karakter Tuhan.65 Banyak istilah yang dipakai oleh para filosof dalam merefleksikan Penyebab Pertama, namun berbagai istilah tersebut memiliki konotasi satu makna.

Prinsip cahaya dikemas dalam teori metafisika "emanasi" (faỵ̣) menjadi kerangka pemikiran utama para filosof Muslim dalam membahas masalah penciptaan. Emanasi alam melalui intelek aktif, oleh al-Farabi dan Ibn Sina didasarkan pada filsafat Neoplatonik. ${ }^{66}$ Keduanya mendasarkan ide-ide tentang Ilahi pada teologi Aristoteles tentang causa efisien pertama, dunia bukan hanya tergantung kepada kehendak Tuhan tetapi pada wujud-Nya. Penciptaan adalah pemberian wujud melalui pantulan cahaya akal sehingga alam semesta terkait dengan sumber ilahinya melalui wujud dan akalnya. ${ }^{67}$ Fungsi cahaya sebagai analogi dalam emanasi oleh Aristoteles, belum mengalami perubahan berarti dalam pemikiran al-Farabi maupun Ibn Sina. Bagi keduanya, efek cahaya dan aksi intelek aktif berada dalam skema yang paralel. Intelek aktif memberikan pada substansi berupa intelek potensial yang berfungsi sebagai cahaya aktual dan berkedudukan menjadi potensi visi.68 Secara garis besar logika potensialitas dan aktualitas menjadi dasar utama dalam merumuskan formulasi penciptaan, baik dalam teori emanasi maupun illuminasi.

Bagi al-Ghazali, penerimaan teori emanasi secara penuh dianggap sangat membahayakan agama. ${ }^{69}$ Dengan mengutip QS. al-Nūr (24): 35 dalam

\footnotetext{
${ }^{65}$ Herbert A. Davidson, Alfarabi, Avicenna, and Averroes on Intellect; Their Cosmologies, Theories of the Active Intellect, and Theories of Human Intelect (Oxford: Oxford University Press, 1992), h. 131-132. Secara spesifik dapat dilihat F.E. Peters, Aristotle and the Arabs: The Aristotelian Tradition in Islam (New York University Press, 1968). h. 44.

66Majid Fakhry, al-Farabi Founder of Islamic Neoplatonism..., h. 47; Herbert A. Davidson, Alfarabi,

${ }^{67}$ Seyyed Hossein Nasr, An Introduction to Islamic Cosmological Doctrines (Cambridge: Harvard University Press, 1994), h. 213.

${ }^{68}$ Herbert A. Davidson, Alfarabi, h. 68.

${ }^{69}$ Penolakan al-Ghazali terhadap teori emanasi, lebih dilandasi oleh alasan teologi Asy'arian tentang keabadian alam sebagai konsekuensi dari teori emanasi dan peniadaan kehendak Tuhan. Abū al-ḥamid Ahmmad Muhammad al-Ghazali, Taḥāfut al-Falāsifah. Diedit oleh Sulaymān Dunyā (Kairo: Dār al-Ma'ārif, 1966), h. 147-149. Para penganut emanasi telah mengingkari konsensus umat Islam bahwa Allah menciptakan segalanya secara langsung. Bagi mereka yang mengaku penciptaan melalui limpahan yang gradual bagi akal-akal dan falak-falak, maka mereka dengan gamblang mengakui adanya pencipta-pencipta lain yang berperan sebagai perantara antara Pencipta Pertama dengan
} 
mengawali karya Miskāt al-Anwār, dia mencoba memberi solusi alternatif dengan memperluas perumpamaan cahaya untuk merepresentasikan alam ketuhanan. ${ }^{70} \mathrm{Al}-$ Ghazali menolak menggunakan istilah emanasi, dia lebih suka menggunakan istilah mencipta (fațara) dan untuk menghindari kontak langsung antara Tuhan dan ciptaan, dia menjelaskan bahwa Tuhan mencipta melalui perintah (amr), ${ }^{71}$ dengan satu proses (yașdur). ${ }^{72}$ Dia tidak menjelaskan bagaimana alam fisik menerima eksistensi, dia hanya menyebutkan bahwa semua eksistensi bergantung pada Tuhan. ${ }^{73}$ Namun demikian, dia belum dapat keluar dari skema teori emanasi dan teologi Aristoteles, ketika menjelaskan tentang "cahaya", pendefinisian istilah-istilah dan susunan alam yang dipakai equivalen dengan berbagai istilah pada teori emanasi. ${ }^{74}$ Secara prinsip tidak ada perbedaan mendasar antara gambaran struktur alam al-Ghazali dengan Ibnu Sina melalui rangkaian proses emanasi. Dia hanya menolak penjelasan Ibnu Sina tentang proses yang berkonsekuensi pada keabadian ciptaan. Sifat paradoksal al-Ghazali dipengaruhi ortodoksi doktrin teologi. ${ }^{75}$ Absoluditas kekuasaan dan kehendak Tuhan masih sangat mendominasi argumentasinya.

Dengan meminjam prinsip emanasi al-Ghazali, Ibn Tufayl menjelaskan bahwa manifestasi kemajemukan diibaratkan proses refleksi terus menerus

makhluk-Nya yang beragam. Di samping itu, jika Allah hanya mengetahui diri-Nya sendiri, sedang akal pertama yang melimpah darinya dapat mengetahui lebih dari itu, yaitu dirinya dan Penciptanya. Hal ini berarti akal pertama lebih sempurna daripada Allah. Lihat al-Ghazali, Tahäfut al-Falāsifah., h. 165-169.

${ }^{70}$ al-Ghazali, Mishkātal-Anwār, trj. W.H.T. William Hanry Tample dengan judul: The Niche for Light (London: Royal Asiatic Society, 1924), h. 12.

${ }^{71}$ Herbert A. Davidson, Alfarabi, h. 134-135. Abū hamīd Ahmad Muhammad al-Ghazali, Mishkāt al-Anwār (Kairo: Dār al-Ma'ārif, 1322), h. 91-92.

72Herbert A. Davidson, Alfarabi, h. 150.

73 Bagi al-Ghazali ungkapan "cahaya" layak diterapkan kepada Tuhan sebagai sumber cahaya yang memberikan eksistensi alam semesta sebagai cahaya yang terpancar dari Cahaya Atas Cahaya. Mehdi Ha'iri Yazdi, The Principle of Epistemology in Islamic Philoshophy; Knowledge by Presence, terj. Yuliani Liputo, Ilmu Hudhuri: Prinsip-prinsip Epistemologi dalam Filsafat Islam (Cet. I: Bandung: Mizan, 1994), h. 37. Melalui pancaran cahaya tersebut al-Gazali hendak mengatakan bahwa penciptaan terjadi secara langsung, Tuhan sebagai sumber segala sesuatu melalui pancaran ini. Seluruh pancaran cahaya ini bergantung kepada Tuhan yang secara esensi juga substansi. Secara lebih luas lihat Abū hamīd Ahmad Muhammad al-Ghazali. Ihyyā' Ulūm al-Dīn, jilid III (Kairo: Dār al-Maāāif, 1995), h. 459-460. Mishkāt, h. 53-69.

${ }^{74}$ Seperti istilah-istilah yang ia pakai yaitu al-Wāhid (yang Esa),al-Aql (Akal), al-Nafs (jiwa), dan alMāddah (materi). Di sisi lain, ia memakai istilah malakūt, jabarūt dan al-mulk. Abū hạamìd Muhammad al-Ghazali, Míyār al-'Ilm diedit oleh Sulaymān Dunya (Kairo: Dār al-Ma'ārif, 1960), h. 285-295.

${ }^{75}$ Al-Fakhriy dan Khalī Jār, Tārīkh al-Falsafat al-Arabiyyah (Beirut: Dār al-Ma'ārif al-'Arabiy, 1959), h. 289. Lihat M. Sa'id Syekh, "al-Ghazali: Metaphysics" dalam M.M. Syarif (ed.). A history of Muslim Philosophy (Jermany: Otto Harrassowitz, 1963), h. 617. 
cahaya Matahari pada cermin-cermin. ${ }^{76}$ Demikian halnya di kalangan Ikhwān alȘafā, postulat herarki alam dijelaskan dengan prinsip bilangan melalui pancaran cahaya ke-Esaan-Nya, akan termanifestasi dalam herarki alam. ${ }^{77}$ Skema yang sama digunakan oleh Said Nursi. ${ }^{78}$ Prinsip cahaya ini dikembangkan Ibn Bajjah secara kontradiktif dengan tesis umum. Baginya, efek cahaya pada medium transparan berada dalam aktualitas, diperoleh melalui warna yang equivalen dengan aktualisasi medium transparan sebagaimana adanya. ${ }^{79}$ Meskipun demikian, tentang isu-isu proses penciptaan, dia tetap bersandar pada kerangka kerja al-Farabi dan Ibnu Sina. ${ }^{80}$

Sementara bagi Suhrawardi, Tuhan diidentifakasikan sebagai CahayaSegala-Cahaya (Nūr al-Anwār) sebagai Sumber segala eksistensi, dari CahayaNya akan keluar cahaya-cahaya lain yang merupakan pilar-pilar alam empiris dan jiwa. ${ }^{81}$ Untuk mengatasi problem pluralitas alam, dengan bahasa filsafat Ibn Sina, dia menambahkan dua aspek yang bersifat "antinomik" yang mengatasi paradoksal pada cahaya emanatif pertama atau akal pertama (Personalitas Ilahi) yaitu bersifat wajib wujud sekaligus wujud kemungkinan atau disebut dangan alam antara (barzakh) yang bersifat maya. ${ }^{82}$ Prinsip antinomi alam antara (barzakh) ini dipertegas oleh Ibn 'Arabi dalam eksistensi potensial (al-a'yān althābitah) yang belum teraktualisasi. Dalam posisi ini terdapat dua dimensi sekaligus: imanensi dan transendensi atau dualitas Pencipta-ciptaan, karena manifestasi alam merupakan aktualisasi dari nama-nama Tuhan. Secara a priori, keduanya adalah tunggal dan secara a posteriori dapat menderivasikan dan sekaligus dapat mereintegrasikan. ${ }^{83}$ Agen kosmogonik cahaya adalah refleksi

\footnotetext{
${ }^{76}$ Bahtiar Hussen Shiddieqiy, "Ibn Tufayl” dalam M.M. Syarif, $A$ history of Muslim Philosophy, h. 534.

${ }^{77}$ Ian Richard Netton, Muslim Neoplatonits; An Introduction to the Thought of Brethrent of Purity (Ikhwān al-Ṣafā) (Edinburg: Edinburg University Press, 1991), h. 34.

${ }^{78}$ Bediuzzaman Said Nursi, From the Risale-i Nur Collection 1: The Words (Istanbul: Sozler Nesriyat, 1992), h. 210; From the Risale-i NurCollection 3: The Flashes Collection (Istanbul: Reyhan Ofset A.S., 2000), h. 184-185; From the Risale-i NurCollection 4: The Rays Collection (Istanbul: Reyhan Matbaasi A.S., 1998), h. 85; From the Risale-i Nur Collection: The Supreme Sign, Observations of a Traveller Questioning Creation Concerning his Maker (California: A Publication of Risale-i Nur Institute of America, t.th), h. 111.

${ }^{79}$ Henry Cobin, Temple and Contemplation (London: Islamic Publications, 1986), h. 3.

${ }^{80}$ Herbert A. Davidson, Alfarabi, h.144.

${ }^{81} \mathrm{Abd}$. al-Qādir Mahmūd, al-Falsafat al-Sūfiyyat fí al-Islām; Mașādiruhā wa Makānatuhā fi al-Dīn wa al-hayāt (Beirut: Dar al-Fikr al-'Arabiy, 1966), h. 445.

${ }^{82}$ Herbert A. Davidson, Alfarabi, h. 171.

${ }^{83}$ A.E. Affifiy, A. Mystical Philoshophy of Muhyid Din Ibn 'Arabi, terj. Syahrir Mawi dan Nandi Rahman, Filsafat Mistik Ibn 'Arabi (Jakarta: Gaya Media Pratama, 1989), h. 99-100.
} 
dari Esensi Tuhan (Dhāt Ilāhiyyah) yang diproyeksikan atas ciptaan melalui cahaya Nama-nama. ${ }^{84}$

Formulasi struktur ontologi Ibn 'Arabi dapat diilustrasikan bahwa kevakuman absolud paralel dengan ke-Esaan Mutlak (Ahadiyyah), Zat yang kedirian-Nya absolud (Huwa) sebagai Impersonalitas Ilahi (Non-Wujud) yang realitasnya penuh misteri (al-ghayb al-muțlaq) sehingga tidak dapat dijangkau oleh pengetahuan dan abstraksi apa pun (tanzih). ${ }^{85}$ Istilah yang sama juga digunakan oleh al-jīli yang menyebutkan bahwa Ahadiyah adalah martabat Zat tanpa atribut apa pun baik nama maupun sifat (tanzih). ${ }^{86}$ Istilah tersebut terkadang dibalik dengan istilah Zat Allah adalah ke-Esaan tersembunyi (alghaib al- Ahadiyah) yang merujuk pada Diri (Huwa) secara independen dan tidak dapat di pahami dan mengerti baik secara ibarat dan isyarat apa pun. ${ }^{87}$

Sementara Personalitas Ilahi, Ibn 'Arabi menggunakan istilah wāhid atau wāhidiyah (tunggal) sebagai agen kosmogonik melalui potensialitas permanen (al-a'yān al-thābitah) yang bersifat maya. Aksi kreatif sama halnya dengan Yang Mutlak terrelatifkan atau Atma sebagai Maya, Impersonalitas Ilahi menampakkan dalam Personalitas Diri dalam bentuk kehadiran nama-nama (haḍarat alasmā') atau penampakan Diri (Impersonal) dalam Diri (Personal). ${ }^{88}$ Personalitas Ilahi yang bersifat antinomik, nama-nama dan sifat paradoksal bersifat tunggal dan tidak dapat dibedakan yang menempati posisi alam antara (barzakh) yang bersifat imanen (tashbïh). ${ }^{89}$ Demikian halnya al-jīli menggunakan istilah wāhid atau wāhidiyyah (nama-nama dan sifat dalam bentuk tunggal) sebagai manifestasi awal dari alam Zat.90

${ }^{84}$ Henry Corbin, Alone with Alone, Creative Imagination in the Süfism of Ibn 'Arabī (New Jersey: Prencinton University Press, 1998), h. 191.

${ }^{85}$ Muhy al-Din ibn 'Arabi, Fusus al-Hikām, ed. A.E. Affifiy (Beirut: Dar al-Kitab al-'Arabi, 1980), h. 54-55, 188. Dapat dilihat juga dalam Muhy al-Din Ibn 'Arabi, Futūhāt al-Makkiyyah, jilid III, ed Ahmad Syams Al-Dīn (Beirut: Dār al-Kutub al-'llmiyah, 2006), h. 434.

${ }^{86} \mathrm{Abd}$ al-Karim bin Ibrahim al-j̄il, al-Insān al-Kāmil; Ma'rifat al-Awākhir wa al-Awāill, jilid I (ttp: Dar al-Fikr, tth.), h. 41-42.

${ }^{87}$ Ibid., h. 22

${ }^{88}$ Henry Cobin, Creative Imagination in the Sufism of Ibn Arabi (Pricenton: Pricenton University Press, 1969), h. 195.

${ }^{89}$ Pluralitas semesta merupakan kristalisasi dari potensialitas permanen yang merujuk pada realitas nama dan sifatyang secara primordial bersifat tunggah (wāhid). Ibn 'Arabi, Futühat, III, h. 436.

${ }^{90} \mathrm{Abd}$ al-Karim bin Ibrahim al--jili, al-Insān al-Kāmil, h.43-44. 
Pemahaman prinsip dasar ontologi tentang transendensi (tanzịh) Impersonalitas Tuhan dan imanensi (tashbïh) Personalitas Tuhan menjadi penting untuk mengatasi kebuntuan logika formal (linier), ${ }^{91}$ terutama dalam memahami kegandaan paradoks yang terrangkum dalam prinsip maya yang bersifat antinomi baik dalam agama dan sains. Dalam prinsip maya, hasrat Ilahi memanifestasikan diri agar segala potensialitas dapat diketahui yang diawali dengan kontigensi, kegandaan dan relatif. ${ }^{92}$ Dalam kenyataannya, alam menunjukkan suatu pengetahuan tentang Esensi, maka Tuhan mengungkapkan kemungkinan-kemungkinan-Nya dengan memproyeksikan diri-nya ke dalam relativitas. Karena Impersonalitas Tuhan mustahil untuk termanifestasi, maka nama-nama Ilahi yang mengacu pada Relativitas atau Maya menderevasikan ke dalam realitas alam.93 Impersonalitas Ilahi melahirkan hal-hal yang harus menjadi, sementara Personalitas Ilahi melahirkan hal yang mungkin menjadi atau tidak menjadi (alam). ${ }^{94}$ Prinsip inilah yang juga akan ditemukan dalam hukum alam dalam pandangan sains modern.

Realitas paradoks tersebut terdapat dalam hukum transmisi cahaya, telah melahirkan dua grand teori dalam fisika modern relativitas dan kuantum. Dalam dunia mikro, gabungan teori relativitas dan asas ketidakpastian disebut dengan kuantum relativistik yang dapat digunakan untuk melacak kesatuan dasar alam dan menjadi karakteristik pemikiran sains modern yang paling penting dan mendasar. Realitas alam tidak lain adalah manifestasi fana dari sebuah medan tunggal atau medan kuantum. Realitas medan, kekosongan, atau kehampaan memiliki potensi kreatif tak terhingga. Sedangkan menifestasi-manifestasi fenomenal (alam fisik) tidak lain bersifat sementara dan illusif. ${ }^{95}$ Fenomena fisik merupakan manifestasi dari eksistensi dan non-eksisten sekaligus atau gerak dan diam pada saat bersamaan (antinomi). ${ }^{96}$ Gambaran yang sama telah

\footnotetext{
${ }^{91}$ Ouspensky memberikan jalan logika alternatif yang dapat mengatasi kebuntuan logika formal dalam memahami prinsip antinomi alam antara (barzakh) yang bersifat maya. Dia ingin membuktian problem I.Kant tentang pemahaman alam yang bagi Kant hanya bersifat kesadaran semata, yaitu dengan logika adigung (supra-logic), logika intuitif, higher logic. Selengkapnya dapat disimak dalam P.D. Ouspensky, Tertium Organum; The Third Canon of Thought a Key to The Enigmas of the World, trj. Nicholas Bessaraboff and Claude Bragdon (New York: Vintage Books, 1970).

92Frithjof Schuon, Hakekat Manusia (Yogyakarta: Pustaka Firdaus, 1997), h. 63.

${ }_{93}^{93}$ Frithjof Schuon, Islam \& Filsafat Perenial (Bandung: Mizan, 1995), h. 186.

${ }^{94}$ Frithjof Schuon, Islam \& Filsafat Perenial, h. 160.

${ }^{95}$ Fritjof Capra, The Tao. h. 246-249.

${ }^{96}$ Ibid., h.173-174.
} 
dicetuskan oleh para sufi bahwa alam tidak lain adalah manifestasi kreatif dari dua kutub yang bertentangan (yin-yang, male-female, nama-nama dan sifat-sifat Tuhan yang berlawanan) yang akan melahirkan eksistensi tak terhingga. Sementara yang mendasari semua realitas adalah kehampaan (para Brahman, Adhi Budha, Tao, atau Ahadiyah). Lebih jauh, dengan teori sains modern, para saintis lebih merujuk pada kesadaran ketimbang kepada objek ${ }^{97}$ Sebuah kesadaran tentang adanya interelasi harmonis alam semesta, bahwa setiap partikel adalah bagian dan sekaligus mengandung seluruh partikel lain. ${ }^{98}$ Kesadaran yang tidak dapat didiskripsikan dengan bahasa dan logika ruangwaktu linier, tetapi dengan bahasa sufi tentang pengalaman kesatuan wujud. Dalam sains, kesadaran tersebut mengarah pada pandangan organisme alam sebagai sebuah jaringan ekologi yang integral. ${ }^{99}$ Di samping itu, sains modern tidak hanya menyediakan kesadaran illusifisme alam, tetapi lewat teknologi, sains modern juga telah menciptakan dunia maya secara global melalui teknologi informatika.

Dalam teori relativitas dan asas ketidakpastian mekanika kuantum juga dapat menguak tata kerja alam penyebab gerak planet dan galaksi yang membentuk "hukum alam" dengan keserbateraturannya. Dalam sains, penyebab ini disebut dengan gaya-gaya alami pengatur alam semesta. Gaya tersebut dapat berupa energi (rawasiya) yang berupa empat macam interaksi pengikat: gravitasi, elektromagnitik, interaksi kuat, dan interaksi lemah. Gaya juga berupa partikel-partikel (al-dhāriyāt) yang bergerak dengan kecepatan maksimal yang dimungkinkan semesta yaitu kecepatan cayaha. Partikel-partkel inilah yang menjadi penyebab penggerak benda-benda alam semesta yang sedemikian berat. Penemuan sains yang luar biasa untuk dapat memahami katakata Tuhan yang menyebutkan: Demi partikel-partikel yang sangat-sangat halus. Yang membawa beban berat. Yang mengalir dengan mudah. Yang membagibagi urusan (QS. al-Dhāriyāt (51): 1-4). Patut disadari bahwa partikel-partikel kuantum yang mampu bergerak pada kecepatan cahaya, tidak lain adalah "cahaya" itu sendiri. Secara konsisten, fenomena jenis mu'jizat apa pun yang

${ }^{97} \mathrm{Ibid.}$, h. 356.

${ }^{98}$ Ibid, h. 350.

${ }^{99}$ Fritjof Capra, The Web of Life; A New Synthesis of Mind and Mett, terj. Saut Pasaribu, Jaring-jaring Kehidupan (Yogyakarta: Fajar Pustaka Baru, 2002). Alfred North Whitehead, Science and The Modern World (New York: Mentor Book, 1962), h. 121-122. 
dikenal dalam agama, sebenarnya tidak bertentangan dengan hukum alam sesuai dengan teori sains modern. Jadi, hukum alam yang didiskripsikan sains modern tidak bertentangan dengan ketetapan dan kesatuan sunnatullah dalam ajaran agama seperti yang tercantum dalam Kitab Suci.

\section{Mono Realitas dalam Agama dan Sains}

Kesatuan wujud hanyalah sebagai konsekuensi logis dari menifestasi pluralitas tunggal dalam Relativitas Wujud yaitu Maya yang akan melahirkan alam dengan pancaran cinta sebagai akibat dari ketakterbatasan Ilahi. Aksi kreatif sama halnya dengan Yang Mutlak terrelatifkan atau Atma sebagai Maya, Impersonalitas Ilahi menampakkan dalam Personalitas Diri dalam bentuk kehadiran nama-nama (haḍarat al-asmā') atau penampakan Diri (Impersonal) dalam Diri (Personal). ${ }^{100}$ Keilahian Pribadi yang mewujud dan bertindak dalam seluruh realitas mengisyaratkan bahwa keseluruhan alam sebagai realitas primodial. Tuhan dari Diri Impersonal tidak dapat disebut Tuhan, karena tidak ada hubungan apapun dengan hamba atau ciptaan, dia hanya dapat disebut sebagai Tuhan hanya kaitannya dengan ciptaan.

Realitas alam yang merupakan manifestasi nama-nama Ilahi yang terangkum dalam intelek Tuhan ( $\left.\mathrm{al}-\mathrm{-}^{\prime} \mathrm{Aql}\right)$ mengisyaratkan bahwa segala sesuatu berasal dari Yang Mutlak dan bergantung kepada-Nya. Alam semesta adalah sebuah kitab dengan huruf-hurufnya yang terdiri dari unsur-unsur kosmik sebagi menifestasi ide-de Tuhan. Jadi, alam adalah pancaran kreatif Tuhan yang mengkristal dalam bentuk ungkapan-ungkapan yang tak terhitung jumlahnya. Secara substansi, alam merupakan kristalisasi dari nafas Yang Maha Pengasih (nafs al-Raḥmān) yang ditiupkan melaui pola-pola dasar (al-a'yān al-thābitah) yang mandasari munculnya seluruh ciptaan. ${ }^{101}$ Namun demikian, keanekaragaman realitas ciptaan bukan berarti mecerminkan keserbaragaman Tuhan sebagaimana yang terdapat pada paham panteisme yang secara definitif menganggap Tuhan dan alam bukan merupakan dua hakekat yang terpisah. ${ }^{102}$ Bagi panteisme, pengakuan kesatuan Yang Tak Berhingga dengan yang

${ }^{100}$ Henry Cobin, Creative Imagination in the Sufism of Ibn Arabi (Pricenton: Pricenton University Press, 1969), h. 195.

101S.H. Nasr, Spiritualitas dan Seni Islam (Bandung: Mizan, 1994), h. 35.

102P.J. Zoetmulder, Manunggaling, h. 2. 
berhingga didasarkan atas kesamaan substansial dari asas ontologis. 103 Sebagaimana Spinoza telah dituduh ateis sehubungan dengan anggapannya bahwa secara substansi, Tuhan sinonim dengan alam. Dia tidak sepakat dengan Aristoteles yang menganggap banyak substansi, menurutnya, substansi hanya ada satu. Baginya, Tuhan adalah nama lain dari alam atau substansi alam. Dalam alam tidak ada kehendak atau perencanaan gerak, yang ada hanya kebetulan sesuai dengan hukumnya yang tidak ada tujuan moral dan tujuan akhir.104 Bagaimanapun Allah, adalah serupa dalam ketakterbandingan-Nya, dan tak dapat dibandingkan dalam keserupaan-Nya.

Prinsip transendensi (tanzịh) impersonalitas Tuhan dan imanensi (tashbīh) personalitas Tuhan menjadi penting dalam menjelaskan kecurigaan terhadap ajaran kesatuan wujud yang diduga mengarah pada kemusyrikan. Pada tataran ketakterbandingan Allah, al-Qur'an menegaskan: "Tak ada sesuatu pun yang serupa dengan-Nya". ${ }^{105}$ Pernyataan tersebut menyangkut pada identitas namanama Allah. Tentu saja Tuhan tidak dapat dibandingkan dengan apapun termasuk segala identitas yang melekat pada-Nya, apakah yang dapat diperbuat setetes air terhadap air samudera. Menyangkut ketakterbandingan Tuhan, adalah Tuhan yang tak dapat dikenal dan dipahami dalam diri-Nya. Prinsip ketakterbandingan Tuhan ini mendapat penekanan khusus bagi ahli syariat dan para teolog atau ahli kalam, terkadang nama-nama Tuhan diungkapkan tidak sesuai dengan citra-Nya. Identitas Tuhan yang tak terbatas diletakkan dalam semacam "tempat hampa moral" dalam satu bingkai Maha kehendak yang tak dapat diperhitungkan dan tak dapat dipahami, bahkan tidak dapat dicintai. ${ }^{106}$ Sikap patuh buta merupakan satu-satunya yang dapat diharapkan dari manusia.

\footnotetext{
103Frithjof Schuon, Hakekat Manusia (Yogyakarta: Pustaka Firdaus, 1997), h. 42-43.

${ }^{104}$ Milton K. Munitz, The Ways of Philosophy ( New York: Macmillan Publishing Co. Inc, 1979), h. 247-256.

${ }^{105}$ QS. al-Syura (42): 11.

106Frithjof Schuon, Islam \& Filsafat Perenial (Bandung: Mizan, 1995), h. 122. Penekanan pada kehendak mutlak Tuhan dalam konsep teologi yang dimaksud Schuon adalah teologi Azy'ariyah. Lihat al-Syahrasāni, al-Milal wa al-Nihal, jilid I (Beirut: Dār al-Kutub al-'Ilmiyah, 1369/1950), h.101. kehendak mutlak Tuhan yang digambarkan secara sembrono dapat dilihat pada Abū al-hasan 'Ali ibn Isma'il alAsy'ari, al-Luma' fí Rad 'alā Ahl al-Zaig wa al-Bada' (Beirut: al-Maktab al-Kațulikiyyah, 1952), h.37. argumen ini juga didukung oleh Imam Ghazali. Lihat Abū hamīd Muhammad ibn Muhammad alGhazāli, Tahafüt al-Falasifah, diedit oleh Sulaiman Dunyā (Kairo: Dār al-Ma’ārif, 1966), h. 90-99. dapat dilhat juga dalam Muhammad Ibrahim al-Fayyuni, al-Imām al-Ghazāli wa '-'Alāqqat al-Yaqīn bayn alNaql (Mesir: Dār al-Fikr al-'Arabi, tth), h. 23-27.
} 
Penekanan terhadap aspek tanzịh yang menempatkan Tuhan seolah sebagai Raja yang steril dari moral dan menuntut kepatuhan buta, adalah sungguh Tuhannya bagi orang sinting, sehingga menganggap amal dan ibadah yang dilakukan sudah cukup sebagai bentuk pengabdian dengan harapan imbalan surga. Padahal, seluruh kepatuhan, ibadah, dan amal kebaikan anak Adam dari awal penciptaan sampai hari akhir hanyalah kegaduhan jika dibandingkan dengan kesempurnaan Tuhan. Hanya melalui anugerah dan kemurahan-Nya seonggok tanah diangkat untuk dapat menghadap ke majlis keabadian-Nya dan diperkenankan untuk menginjakkan di atas keluasan hamparan permadani rahmat-Nya. ${ }^{107}$ Memahami Allah sebagai yang jauh dan tak terjangkau melalui kebesaran, keagungan, kekuasaan, dan kesuciannya adalah hanya mengambil satu aspek pertama dari formulasi syahadat dalam Islam. Jadi jelas bahwa jika hanya mengedepankan aspak ketakterbandingan akan menghasilkan ta'țil, bahwa Allah sama sekali tidak ada hubungannya dengan alam. Sementara dalam aspek lain al-Qura'an menyebutkan: "Allah senantisa bersamamu di manapun kamu berada". 108 "Dia lebih dekat kepada dirimu ketimbang urat lehermu". 109 "ke mana pun kamu berpaling dan menghadap di situlah wajah Allah".110 Kedekatan, kebersamaan, dan wajah Tuhan hanya dapat ditemui melalui jejakjejak nama-Nya yang termanifestasi dalam alam. Oleh karena itu, kita tidak dapat mengenal Tuhan dalam diri-Nya, kita hanya dapat mengenal Tuhan sejauh Dia menyingkapkan diri-Nya melalui alam.

Pluralitas alam dengan segala paradoks yang membentuk pasanganpasangan akan melahirkan tatanan harmonis mencerminkan sebuah pola kerja yang seragam dan tunggal sebagai sebuah tarian kosmik yang seimbang. ${ }^{111}$ Pola berpasangan merupakan pola dasar yang bekerja di alam semesta yang membentuk hukum alam yang secara primordial merupakan sunatullāh. Primordialisme hukum alam dapat ditelusuri dari prinsip Ilahiyah melalui aspek tanzịh yang bersifat aktif (yang) dan tashbïh yang bersifat reseptif (ying). Pola ini dapat dijumpai dalam prinsip tajalliyat (penampakan) nama-nama dalam diri

${ }^{107}$ Sachiko Murata, The Tao, h. 83.

${ }^{108}$ QS. al-Hadid (57): 4.

109 QS. Qaf (50): 16.

110 QS. al- Baqarah (2): 115.

111 "Segala diciptakan berpasang-pasangan baikyang tumbuh dari bumi, dari dirinya sampai yang belum dikatahui” lihat QS. Yasin (36): 36. 
Tuhan.112 Pola yang sama dapat ditemukan dalam tataran Wujud atau Personalitas Ilahi, nama-nama yang melekat dalam Diri-Personal saling berlawanan tetapi membentuk satu kesatuan yang tunggal dan tidak dapat dibedakan sebagai entitas-entitas permanen atau dapat disebut sebagai hakikat alam semesta. ${ }^{113}$ Dengan demikian, pola tata kerja alam tidak pernah menyimpang dari prinsip primodialnya, sunnah Allah tidak akan pernah berubah. ${ }^{114}$ Hanya milik Tuhan segala ciptaan beserta hukumnya $(\mathrm{amr}) .{ }^{115}$ Realitas alam tidak lain adalah luapan wujud dari nilai-nilai samawi malalui firman: "jadilah" (kun), seluruh manifestasi alam beserta hukum (amr) akan terwujud dengan tanpa akhir. Jadi, setiap saat, alam selalu berada dalam genggaman kun sebagai satu aksi kreatif dari hembusan nafas yang tiada henti.

Kegandaan paradoks yang terangkum dalam prinsip maya atau relativitas menyertai aksi kreatif Tuhan menjadi hukum yang berlaku bagi seluruh realitas. Dalam prinsip maya, hasrat Ilahi memanifestasikan diri agar segala potensialitas dapat diketahui yang diawali dengan kontigensi, kegandaan dan relatif.116 Dalam kenyataannya, alam menunjukkan suatu pengetahuan tentang Esensi, maka Tuhan mengungkapkan kemungkinan-kemungkinan-Nya dengan memproyeksikan diri-nya ke dalam relativitas. Karena Impersonalitas Tuhan mustahil untuk termanifestasi, maka nama-nama Ilahi yang mengacu pada Relativitas atau Maya menderevasikan ke dalam realitas alam. ${ }^{117}$ Personalitas Ilahi yang menyangkut nama-nama adalah Wujud Relativitas yang bersifat Maya atau Yang Mungkin, tetapi sifat-sifat Personalitas Ilahi dalam Impersonalitas masing-masing sesuai dengan Esensi yang telah mencakup tatanan kemungkinan-kemungkinan dan mengandung keharusan mutlak dari Esensi. Impersonalitas Ilahi melahirkan hal-hal yang harus menjadi, sementara Personalitas Ilahi melahirkan hal yang mungkin menjadi atau tidak menjadi

\footnotetext{
112Dalam istilah Ibn 'Arabi disebut dengan al-fayd al-aqdas yang ditandai dengan kehadiran nama-nama (haḍarat al-asmā'), dapat disebut juga dengan penampakan diri esensi (tajalli al-dhāti). Azhari Noer, Ibn 'Arabi, h. 63. Tentu identias waktu tidak dapat disertakan dalam proses penempakan nama-nama, menurut hukum relativitas, dalam energi murni waktu manjadi nol, Tuhan adalah sumber segala energi sehingga waktu menjadi awal-akhir yang tidak dapat dibedakan.

${ }^{113}$ Segala kejadian yang di alam semesta berada dalam genggaman ilmu Allah yang bersifat azali, karena realitas alam tidak lain adalah aktualisasi dari entitas-entitas permanen tersebut. Ibid.h. 120.

${ }^{114}$ QS. Fatir (35): 43.

115QS. al-A'raf(7): 54.

116F. Schuon, hakekat, h.63.

117F. Schuon, Perenial, h. 186.
} 
(alam).118 Prinsip inilah yang juga akan ditemukan dalam hukum alam dalam pandangan sains modern.

Dalam sains modern memandang bahwa basis realitas alam adalah manifestasi gelombang yang mengandung situasi paradoks (energi-materi) dari hubungan alam ganda dalam bentuk radiasi. Fenomena gelombang bekerja atas dasar relativitas dan asas ketidakpastian. Oleh karena itu, sejauh hukum yang ditemukan manusia mengacu pada realitas, maka hukum itu pastilah tidak pasti. Realitas alam menunjukkan aktivitas tanpa henti dari interaksi-interaksi dari aliran energi yang memanifestasikan diri sebagai pertukaran partikelpartikel,119 yang diciptakan dan dihancurkan tanpa akhir dalam variasi berkelanjutan dari pola-pola energi. Interaksi partikel melahirkan strukturstruktur stabil yang membentuk dunia materi, partikel tidaklah statis dan diam, tetapi bergerak tanpa pernah henti yang membentuk ritmis. Seluruh realitas alam berada dalam ikatan gerak dan aktivitas abadi tarian kosmik yang berkesinambungan dengan energi.

Equivalensi antara materi dan energi telah memaksa para ilmuan tidak dapat memandang alam sebagi sesuatu yang statis dan eksaks. Realitas dan tata kerja alam yang tercipta oleh interaksi energi-partikel adalah sesuatu yang paling mendasar dalam pandangan sains modern. Dalam proses interaksi energi-patikel dalam gelombang, umur partikel hanya sekitar seperejuta detik ${ }^{120}$ Konsekuensinya adalah dalam satu detik itu juga alam ini telah berganti satu juta kali. Di saat yang sama, pertikel tidak lain adalah gelombang dan sebaliknya. Sementara dalam gelombang mengandung aspek paradoks yang tak dapat dibedakan, antara partikel dan gelombang, antara materi dan energi. Paradoks yang mendasar dalam fenomena gelombang adalah menifestasi eksistensi dan non-eksistensi, karena partikel menunjukkan dirinya ada dan tidak ada pada saat dan tempat yang sama, diam dan gerak sekaligus. ${ }^{121}$ Dengan demikian, alam sebenarnya ada dan tidak ada dalam saat yang sama serta gerak dan diam sekaligus. Logika mendasar semesta ini bagi Ouspensky disebut dengan Higher logic, trancendental logic, intuitive logic, dan the logic of infinity

118Ibid, h. 160.

${ }^{119}$ F. Capra, Tao, h. 264.

${ }^{120} \mathrm{Ibid}, \mathrm{h} .240$.

121 Ibid, h. 273. 
yang dapat mengatasi dualitas fenomena profan wujud empiris.122 Realitas alam yang dipahami sains modern nampaknya menyadarkan pada kita bahwa selama ini logika linier yang digunakan untuk membangun ilmu pengetahuan secara luas adalah keliru dan absud.

Dari formulasi fenomena gelombang yang mendasari semua proses interaksi adalah realitas medan kuantum. Realitas medan adalah kekosongan atau kehampaan yang di dalamnya mengandung angka tak terbatas dari partikelpartikel yang ada dan hilang tanpa jejak, sehingga memiliki potensi kreatif dan pemusnahan yang tak terhingga. ${ }^{123}$ Hal tersebut mengisyaratkan bahwa seluruh tataran realitas setiap saat tercipta dan sekaligus kembali kepada asal-usul. ${ }^{124}$ Realitas alam atau fenomena-fenomena fisik adalah sebagai menifestasi fana dan bersifat ilusif dari sebuah kesatuan dasar medan yang fundamental. Kehadiran materi hanya sekedar gangguan dari keadaan sempurna dari sebuah medan kuantum. ${ }^{125}$ Sementara dalam teori kuantum, partikel tidak dapat dipastikan posisi dan momentumnya, tetapi lebih menunjukkan kemungkinan untuk ada dan menjadi. Apakah dengan demikian realitas alam termasuk diri kita sebernarnya hanyalah kehampaan belaka. Kehampaan bukanlah nihilisme, tetapi realitas keagungan yang tak terbahasakan dengan mengandung segala kemungkinan dari seluruh ide penciptaan tanpa batas. Kehampaan semesta merefleksikan adanya kedamaian abadi yang di dalamnya gema firman Tuhan termanifestasi, sebagaimana dalam Impersonalitas Ilahi dengan identitas Personalitas nama yang memuat seluruh gagasan penciptaan dengan segala kemungkinannya, dan melalui nafas kasih sayang segala realitas terwujud.

Dengan melihat fenomena alam transparan yang ditunjukkan oleh pandangan alam dalam sains modern, menyadarkan kita bahwa sebenarnya tidak ada pijakan realitas apapun bagi kita untuk dapat berlindung, karena perlindungan apapun selain Allah bagaikan sarang laba-laba. ${ }^{126}$ Menyadari realitas alam sebagaimana dalam sains modern menyadarkan manusia pada realitas diri dan sekelilingnya bukanlah apa-apa dan bukan siapa-siapa. Di

122P.D. Ouspensky, Tertium Orgonum the Third of Thought a Key to the Anigmas of the World (New York: Vintage Books, 1970), h. 235-236.

123 Ibid, h. 262.

${ }^{124}$ Lihat QS. Yasin (36): 83.

125 Ibid, h. 252.

${ }^{126}$ QS. al-'Ankabut(29): 41. 
samping itu, sains modern memandang alam bukanlah terpisah dari bagian properti yang lain, tetapi sebagai jaringan organisme tunggal yang dapat ditunjukkan pula oleh fenomena partikel bahwa setiap partikel adalah bagian dan sekaligus mengandung seluruh partikel lain.127 Sebuah kesadaran yang tidak dapat didiskripsikan dengan bahasa dan logika linier, tetapi bukan hal yang asing bagi bahasa kearifan dalam tradisi agama tentang kesatuan wujud. Dengan demikian, sains modern telah dapat mengantarkan kita pada kesadaran tentang kehadiran Tuhan dalam segala aspek realitas dan dapat merasakan keagunganNya yang tak terselami. Lebih jauh sains modern telah mampu menyingkap rahasia prinsip Ilahi dalam hamparan semesta, sebagaimana ungkapan Ibn 'Arabi bahwa segala yang tercipta dalam eksistensi hanyalah illusif, tetapi sesungguhnya segalanya adalah al-Haqq, dan barang siapa yang memahami kebenaran tersebut, sesungguhnya telah menyingkap mesteri jalan Tuhan.

Tidak sebagaimana dalam sains klasik Newtonian dengan mekanisme matematis, alam digambarkan bagaikan mesin raksasa yang dikendalikan oleh daya masing-masing. Gambaran alam yang statis dalam ruang waktu absolud seolah tidak memberi celah bagi hadirnya Pencipta dalam proses tata kerja alam. Satu-satunya jawaban yang tampak apologis dan inkonsisten dengan ruang waktu absolud adalah bahwa pada waktu tertentu, Tuhan telah menciptakan alam seperti yang ada sekarang. Dampak paling fatal dari pandangan determinisme alam sains klasik adalah berujung pada kematian Tuhan melalui filsafat Nitze dan disempurnakan dengan kematian manusia lewat filsafat bahasa. ${ }^{128}$ Sementara dalam sains modern, melalui teori relativitas dan asas ketidakpastian, sains modern mampu melacak asal-asul alam semesta. Dengan mengambil antitesa keruntuhan bintang (supernova) yang membentuk lubang hitam dan akhirnya membentuk titik nol (singularitas), Stephen Hawking mengembangkan gagasan Gamow tentang dentuman besar (big bang) sebagai awal terjadinya alam semesta dari sebuah titik sengularitas. ${ }^{129}$ Sekitas 15 miyar

127 Ibid, h. 350.

${ }^{128}$ Kekhawatiran pertama disampaikan oleh Libniz tentang bahaya musnahnya agama dari efek fisika Newton. Louis Leahy SJ, Filsafat Ketuhanan Kontemporer (Yogyakarta: Kanisius, 1993), h. 59. terdapat perbincangan menarik antara pendukung Newton (Clarke) dengan Libniz tentang hubungan sains klasik dan agama. Libniz and Clarke, "Contoversi on Time and Creation" dalam Baruch A. Brody (ed.), Reading in Philosophy of Relegion an Analytic Approach (USA: Prentice Hill, Inc, 1974), h. 436-438.

${ }^{129}$ Stephen Hawking, Riwayat Sankala; karya lain, Lubang Hitam dan Jagat Bayi dan Esai-esai lain (Jakarta: Gramedia, 1995); Ketty Ferguson, Stephen Hawking; Pencarian Teori Segala Hal Uakarta: Pustaka Utama Grafiti, 1995). 
tahun yang lalu alam semesta masih didominasi oleh radiasi yang masih besar dan dipengaruhi oleh gravitasi. Sementara big bang terjadi 700.000 tahun sebelumnya. ${ }^{130}$ Namun demikian, teori sains modern belum mampu menembus titik singularitas, karena tidak ada teori sains yang mampu mengatasi ketakberhinggaan, realitas yang dapat dideteksi oleh sains adalah mendekati waktu nol $10^{-43}$ (waktu planck). ${ }^{131}$ Oleh karena itu obsesi besar fisikawan adalah menemukan teori tunggal yang dapat memerikan semesta secara penuh, termasuk fenomena kehidupan.

Bagaimanapun penemuan sains menunjukkan upaya pencarian manusia dalam menguak rahasia yang terpendam di hamparan semesta. Sebagaimana Martin Heidegger mengungkapkan pembentukan struktur dasar konsepsi ontologis struktur bentuk realitas melampaui hubungan subjek-objek yang secara kongkrit "ada" sebagai sesuatu yang abstrak, hidup dan dinamis. ${ }^{132}$ Fenomena singularitas dan kevakuman dalam teori medan menunjukkan bahwa dalam realitas titik nol, seluruh manifestasi realitas terangkum. Dalam prisip Heideggerian disebut dengan menahan diri (defranc), dalam sains disebut dengan gravitasi dan dalam tradisi agama disebut dengan prinsip sabar. Singulatitas, kevakuman, kehampaan bukan berarti ketiadaan eksistensi (nihil), tetapi merupakan hijab sekaligus pintu gerbang menuju gudang kearifan bagi seluruh tatanan realitas. ${ }^{133}$

\section{E. Implikasi dan Relefansi}

Secara mendasar, baik agama maupun sains, masing-masing memiliki nilai yang berpengaruh besar dalam membentuk ideologi dan struktur sosial yang menjadi pilar peradaban. Kesamaan cara pandang antara agama dan sains dalam menelusuri jejak muasal realitas melalui prinsip cahaya atau energi.

${ }^{130}$ Kenneth S. Krane, Fisika Modern (Jakarta: UI Press, 1992), h. 710.

${ }^{131} \mathrm{Ibid}, \mathrm{h} .711$.

${ }^{132}$ Anthony C.Thiselton, Horizons in Hermeneutics (Michigan: Zondervan Publishing House, 1992), h. 279.

133Kondisi zero level ini dalam tradisi agama disebut dengan kondisi ketenangan (mutmainnah) sebagai prasyarat kelayakan untuk mendapat panggilan menghadap sang Pencipta dan layak diangkat sebagai hamba-Nya. Lihat QS. al-Fajr (89): 27-29. Sebagaimana Musa diharuskan melepas seluruh identitas dirinya (dengan simbol melepas kedua terompahnya) agar dapat dianggap layak untuk menghadap, demikian halnya Ibrahim untuk diangkat sebagai imam, harus melampaui seluruh ujian yang diberikan. 
Mentalitas yang akan dibangung oleh sains modern adalah cara pandang terhadap seluruh realitas secara holistik. Sebuah pandangan yang menganggap bahwa seluruh fenomena sebagai satu kesatuan fundamental dengan menunjukkan pola dasar yang sama dimana tidak ada ruang sekecil apapun yang statis. Pandangan illusifisme alam dalam sains modern telah termanifestasi dengan terciptanya dunia maya yang telah mengantarkan pada era global. Realitas maya yang diperkenalkan sains modern bahwa segala sesuatu adalah illusif sebagaimana yang dipertontonkan setiap hari, berbagai tayangan adegan di televisi, radio, telpon, informasi di internet semuanya bersifat illusif, karena yang mendasari seluruh fenomena tersebut adalah gelombang, demikian halnya realitas alam. Realitas gelombang berperilaku relatif dan serba mungkin, sementara yang mendasari realitas gelombang adalah kehampaan. Mesin cerdas berupa komputer yang menjadi perangkat penting kerja manusia adalah bekerja atas dasar hukum gelombang. Revolusi teknologi yang tercipta oleh sains modern seharusnya dapat mengantarkan pada kesadaran manusia bahwa pada dasarnya setiap realitas adalah illusif. Namun sayang mentalitas semacam itu belum banyak pengaruh, karena masih didominasi oleh mentalitas materialisme konsumeris bentukan sains klasik.

Sesuai dengan hukum alam yang diformulasikan dalam teori sains modern menunjukkan bahwa berbagai pengalaman spiritualitas dalam agama yang berupa mu'jizat atau sejenisnya tidak lagi dipandang sebagai sesuatu yang tahayul atau irrasional dan tidak ilmiah, teori sains modern, alam dengan hukumnya yang berlaku memungkinkan terjadinya fenomena kemu'jizatan sebagaimana dalam pengalaman keagamaan, dan tetap berlaku bagi setiap realitas. Obsesi visi ilmiah para saintis untuk merealisasikan fenomena keagamaan tersebut baru diwujudkan dalam berbagai judul film: Time Tannel, yang menggambarkan sebuah visi menembus ruang waktu; Powder, yang menggambar anak ajaib yang lahir dari energi halilintar yang dapat berperilaku sebagaimana Isa, Matrix, yang menggambarkan manusia illusif, dan masih banyak yang lain. Jika obsesi saintis dalam mencari teori tunggal dapat tercapai, niscaya tahap yang akan terjadi adalah revolusi spiritual yang menandai puncak peradaban manusia di muka bumi.

Nampaknya peradaban ke depan akan menemukan pijakan yang benar untuk menciptakan suasana hormonis dalam segala aspek. Apakah dengan demikian akan terbentuk peradaban paripurna yang akan mengakhiri sejarah 
pencarian manusia terhadap rahasia alam dan diri manusia. Atau apakah hal tersebut menunjukkan hasil aksperimentasi akhir Tuhan terhadap anak cucu Adam dalam memahami realitas nama yang diajarkan sebelum penciptaan. Semuanya masih dalam proses dan bergantung pada bagaimana para pelaku sejarah ini mengkonstruksi masa depannya.

Nampak jelas sudah bagaimana perjalanan sains yang digagas manusia dalam mengemban amanat dalam mereintegrasikan kembali realitas nama yang diajarakan Tuhan ke dalam diri dan realitas. Benturan antara agama dan sains sudah tidak lagi menjadi isu aktual yang perlu diperdebatkan. Pada saat ini keduanya saling beriringan dalam membentuk peradaban yang damai dan harmonis Di sinilah Islam memposisikan diri sebagai agama yang paling strategis dan memiliki peluang yang lebih besar dalam menentukan arah peradaban manusia ke depan. Tinggal bagaimana umat Islam dapat mensikapi dan menerjemahkan fenomena tersebut dalam menciptakan peradaban yang dipenuhi berkah Ilahi.]

\section{DAFTAR PUSTAKA}

Affifiy, A.E. Filsafat Mistik Ibn 'Arabi, Jakarta: Gaya Media Pratama, 1989.

al-Asfahāni, al-Raghīb. Mu'jam Mufradāt Alfāz al-Qur'ān, Beirut:dar al-Fikr, 1972.

al-Asy'ari,Abū al-Ḥasan 'Ali ibn Isma'il, al-Luma'fi Rad 'alā Ahl al-Zaig wa al-Bada' Beirut: al-Maktab al-Kațulikiyyah, 1952.

al-Ibānah 'an 'Ușūl al-Diyānah, Beirut: Dār al-Kutub al-'Ilmiyah, tth.

al-'Akkad, Abbas Mahmoud. Ketuhanan, Sepanjang Ajaran Agama-agama dan Pemikiran Manusia, Cet. II; Jakarta: Bulan Bintang, 1972.

al-Azraq, Mustafa Majid, Tamhïd li Tārïkh al-Falsafaț al-Islāmiyyah. Cet. III; Kairo: Lajnah al-Ta'lif wa al-Tarjamat wa al-Nasyr, 1379/1959.

Bagis, Zainal Abidin (et al), Integrasi Ilmu dan Agama Interpretasi dan Aksi, Bandung: Mizan, 2005.

Bagus, Lorens. Metafisika. Jakarta: Gramedia, 1991.

al-Bāqi, Muhammad Fu’ād. al-Mu'jam al-Mufahras li Alfāz al-Qur'ān al-Karīm. Beirut: Dar al-Fikr, 1987. 
Barbour, Ian G., When Science Meets Relegion: Enemies, Strangers, or Partuers?, terj. E.R. Muhammad, Juru Bicara Tuhan antara Sains dan Agama. Bandung: Mizan, 2002.

Bergmann, Peter Gabriel. Introduction to Theory of Relativity. Tokyo: Japan Publication Trading, Co. Ltd., 1961.

Bertens, Sejarah Filsafat Yunani. Jakarta: Kanisius, 1975.

Blavatsky, H.P., Isis Unveiled, A Master-Key to the Mysteries of ancient and Modern Science and Theology, jilid I. California: The Theoshopical Publishing Company Point Lama, 1906.

The Secret Doctrine, jilid I. Madras: The Theosophical Publishing House, 1987.

al-Bukhari, Abu Abdillah Isma'il. al-Jami' al-Sahih. Beirut: Dar al-Kutub al-Ilmiyah, 1412/1992.

Burkhardt, Barry Smith, Hans (eds.), Handbook of Metaphysics and Ontology. Munich: Philosophia Verlag, 1991.

Capra, Fritjof. Tao of Physic: Menyingkap Paralelisme Fisika Modern dan Mistisisme Timur. Yogyakarta: Jalasutra, 2001.

Titik Balik Peradaban, Sains, Masyarakat dan Kebangkitan Kebudayaan. Yogyakarta: Bentang, 1997.

The Web of Life; A New Synthesis of Mind and Mett, terj. Saut Pasaribu, Jaring-jaring Kehidupan. Yogyakarta: Fajar Pustaka Baru, 2002.

Carroll, William E, God and Physics: From Hawking to Avicenna. www.Muslimphilosophy.com/sina/art/gpa.doc.

Chalmers, A.F. Apa itu Yang dinamakan Ilmu? Suatu Penilaian Tentang Watak dan Status Ilmu Serta Metodenya. Jakarta: Driyakara, t.th.

Cobin, Henry. Alone with Alone, Creative Imagination in the Süfism of Ibn 'Arabi. New Jersey: Prencinton University Press, 1998 Temple and Contemplation. London: Islamic Publications, 1986.

Davidson, Herbert A. Alfarabi, Avicenna, and Averroes on Intellect; Their Cosmologies, Theories of the Active Intellect, and Theories of Human Intelect. Oxford: Oxford University Press, 1992. 
Devies, Paul, God and New Physic. New York: Simon \& Schuster, 1969. Mind of God. New York: Touchstone, 1983.

Descartes, Rene. "Two Traditions" dalam Rendall Buchler dan Shirk (ed.), Reading Philosophy. New York: Barnies \& Nober Inc, 1950.

Easton, Atewart C., The Heritage of the Past, Fram the Earliest Time to the Close of the Middle Ages. New York: Holt, Rinehart and Winston, 1963.

Einstein, Albert. Relativity, the Special and the General Theory. New York: Bonanza Books, 1952.

Fakhry, Majid, al-Farabi Founder of Islamic Neoplatonism, His Life, Works, and Influence. Oxford: Oneworld, 2002.

al-Fayyuni, Muhammad Ibrahim, Al-Imām al-Ghazāli wa al-'Alāqat al-Yaqīn bayn al-Naql. Mesir: Dār al-Fikr al-'Arabi, t.th.

Farber, Marvin. The Foundation of Phenomenology. Edmund Husserl and the Quest for a Rigorous Science of Philosophy. Cambridge: Harvard University Press, 1943.

Ferguson, Ketty, Stephen Hawking; Pencarian Teori Segala Hal, Jakarta: Pustaka Utama Grafiti, 1995.

Fuller, J.F.C., The Secret Wisdom of the Qabalah: A Study in Jewish Mistical Thought. ttp: tth.

Gadamer, Hans-Goerge, philophical Hermeneutics, translated and edited by David E. Linge. Los Angeles: University of California Press, 1977.

al-Ghazāli, Abū H\}amīd Muhammad ibn Muhammad, Miskāt al-Anwār. Kairo: Dār al-Ma’ārif, 1322.

Ma'arij al-Quds fi Madārij Ma'rifat al-Nafs, diedit oleh Muhy al-Din alKurdi. Kairo: Dār al-Ma'ārif, 1327.

Tahafūt al-Falasifah, diedit oleh Sulaiman Dunyā. Cet iv; Kairo: Dār alMa'ārif, 1966.

Ihyyā' 'Ulūm al-Dīn, jilid III. Kairo: Dār al-Ma'ārif, 1995.

, Mi'yār al-'Ilm diedit oleh Sulaymān Dunya. Kairo: Dār al-Ma'ārif, 1960.

Grunebaum, G.E. Von, Classical Islam, a History 600-1258. London: George Allen \& Unwin Ltd., 1970. 
Hadi, P. Hartono. Epistemologi Filsafat Pengetahuan. Yogyakarta: Kanisius, 1994.

Haught, John F., Sccience and Religion: From Conflict to Conversation, terj. Fransiskus Borgias, Perjumpaan Sains dan Agama, dari Konflik ke Dialog. Bandung: Mizan, 2004.

Hawking, Stephen. Riwayat Sang Kala, dari Dentuman Besar hingga Lubang Hitam. Jakarta: Grafiti, 1993. Lubang Hitam dan Jagat Bayi dan Esai-Esai lain Jakarta: Gramedia, 1995.

Heidegger, Martin, Being and Time: Translation of Sein and Zeit. New York: New York University Press, 1996.

Husserl, Edmund, Ideas: General Introduction to Pure Phenomenology. New York: Collier Books, 1962.

http://einsteinandreligion.com/scienceandreligion.html

http://whatis.techtarget.com/definition/convergence

http://www.merriam-webster.com/dictionary/convergence

Ibn 'Arabi, Muhy al-Din, Fusus al-Hikam, ed. A.E. Affifiy. Beirut: Dar al-Kitab al'Arabi, 1980.

Futūhạat al-Makkiyyah, jilid III, ed. Ahmad Syams Al-Dīn. Beirut: Dār alKutub al-Ilmiyah, 2006.

Ibn Hanbal, Ahmad. Musnad. Beirut: dar al-Kutub al-'Arabi, 1979.

Ibn Majah, Abu Abdillah ibn Yazid al-Qazwini. Sunnah Ibn Majah. Beirut: Dar alFikr, t.th.

Iqbal, Muhammad. Rekonstruksi Pemikiran Agama dalam Islam. Yogyakarta: Jalasutra, 2002.

al-Jabiri, Muhammad 'Abid, Bunyah al-'Aql al-'Arabi: Dirāsat Tahlïliyyah Naqdiyyah li Nuḍūm al-Márifah fi al-Saqāfah al'Arabiyyah. Beirut: al-Makaz al-Saqafi al'Rabi, 1993.

Jaki, S.L., Cosmos and Creator. Endinburg: Endinburg University Press, 1980. God and the Cosmologist. Endinburg: Endinburg University Press, 1989.

al-Jili, 'Abd al-Karim bin Ibrahim, al-Insān al-Kāmil; Ma'rifat al-Awākhir wa alAwāill, jilid I. ttp: Dar al-Fikr, t.th. 
Kant, Immanuel. Critique of Pure Reason. Cambridge: Cambridge University Press, 1998.

Karam, Yūsuf, Tārikh al-Falsafat al-Hadīthah. Mesir: Dar al-Ma'ārif, t.th.

Komaruddin Hidayat dan Muhammad Wahyuni Nafis, Agama Masa Depan Perspektif Filsafat Perenial Jakarta: Paramadina, 1995.

Krane, Kenneth S. Fisika Modern. Jakarta: UI Press, 1992.

Libniz \& Clark, "Controversy on Time and Creation" dalam Baruch A. Brody (ed.), Reading in Philosophy of Religion an Analitic Approach. U.S.A: Printice Hill, Inc, 1974.

Leahy, Louis. SJ, Filsafat Ketuhanan Kontemporer. Yogyakarta: Kanisius, 1993.

Lindberg, David, The Beginings of Western Science: The European Scientific Tradition in Philosophical, Religious, and Institutional Context, 600 B.C. to A.D. 1450. Chicago: Chicago University Press, 1992

al-Mansuriy, Muhammad bin Mukrim bin Mazur al-Afriqiy. Lisan al-Arab jilid v. Beirut: Dar Iyha' al-Turas, 1996.

May, S. Iqbal His Life and Time. Lahore: Sh. Muhammad Asraf, 1964.

Mill, John Stuart. "Nature" dalam Rendal Buchler dan Shirk (ed.), Reading Philosophy. New York: Barnies \& Nober Inc, 1950.

Madkour, Ibrahim, Fī al-Fasafat al-Islāmiyah Manhaj wa Tatbiquh, jilid I. Kairo: Dār al-Ma'ārif, 1981.

Murakami, Kazuo, The Divine Messege of DNA, Tuhan dalam Gen Kita. Bandung: Mizan, 1997.

Muhmud, Abd al-Qadir. al-Falsafat al-Sufiyat fi al-Islam; Mașadiruhā wa Makānatuhā fi al-Dīn wa al-Hayāt. Beirut: Dar al-Fikr al-'Arabi, 1966.

Munitz, Milton K. The Ways of Philosophy. New York: Macmillan Publishing Co. Inc, 1979.

Murata, Sachiko. The Tao of Islam, Kitab Rujukan tentang Relasi Gender dalam Kosmos dan Teologi Islam. Bandung: Mizan, 1992.

Muslim, Imam. Sahih. Beirut: dar al-Fikr, t.th.

Nasr, Sayyed Hossein. Spiritualitas dan Seni Islam. Bandung: Mizan, 1994. 
Islam dan Nestapa Dunia Modern. Bandung: Pustaka, 1983.

Pengetahuan dan Kesucian Yogyakarta: Pustaka Pelajar, 1997.

Science and Civilization in Islam. Cambridge: Harvard University Press, 1968

Nasution, Harun. Islam Rasional. Bandung: Mizan, 1996.

al-Nasāì, Sunan al-Nasā'i, jilid IV. Beirut: Dār al-Fikr, 1348 H / 1930 M.

Needham, Joseph. Man and Mechine. New York: Norton, 1962.

Netton, Ian Richard. Muslim Neoplatonits; An Introduction to the Thought of Brethrent of Purity (Ikhwān al-Ṣafā). Edinburg: Edinburg University press, 1991.

Noer, Kautsar Azhari. Ibn 'Arabi: Wahdat al-Wujud dalam Perdebatan, Jakarta: Paramadina, 1995.

Nursi, Bediuzzaman Said, From the Risale-i Nur Collection 1: The Words. Istanbul: Sozler Nesriyat, 1992.

From the Risale-i NurCollection 3: The Flashes Collection. Istanbul: Reyhan Ofset A.S., 2000.

From the Risale-i NurCollection 4: The Rays Collection. Istanbul: Reyhan Matbaasi A.S., 1998.

From the Risale-i Nur Collection: The Supreme Sign, Observations of a Traveller Questioning Creation Concerning his Maker. California: A Publication of Risale-i Nur Institute of America, tth

Otto, Rudolf, Mysticism East and the Waest; a Comparative Analysis of The Nature of Mysticism (cet. iii; New York: The Macmillan Company, 1972

Ouspensky, P.D., Tertium Organum; The Third Canon of Thought a Key to The Enigmas of the World, trj. Nicholas Bessaraboff and Claude Bragdon.New York: Vintage Books, 1970.

Qadir, C.A. Filsafat dan Ilmu Pengetahuan Dalam Islam. Jakarta: Yayasan Obor Indonesia, 1991.

Peters, F.E., Aristotle and the Arabs: The Aristotelian Tradition in Islam. New York University Press, 1968. 
Poedjawijatna, Pembimbing ke Arah Alam Filasafat. Jakarta: Rineka, 1990.

Rahman, Fazlur,. Islam. Chicago: Chicago University Press, 1979.

Robin Le Poidevin Robin (ed. et al). The Routledge Companion to Metaphysics. New York: Routledge 2009.

Runes, Dagobert D., dictionary of Philosophy. New Jersy : Little Adam \& Co, 1976.

Russel, Bertrand. History of Western Philosophy. Oxford: Alden Press, 1974.

Schuon, Frithjof. Hakekat Manusia. Yogyakarta: Pustaka Firdaus, 1997. Islam \& Filsafat Perenial. Bandung: Mizan, 1995. Understanding Islam. London: Unwin Paperback, 1976.

Schimmel, Annemarie. Rahasia Suci Wajah Ilahi. Bandung: Mizan, 1996

Shibel, Fuad Muh, Kebudaan Islam Menurut Toynbee. Jakarta: Bulan Bintang, 1977.

Shihab, M. Qraish. Wawasan al-Qur'an. Bandung: Mizan, 1996.

Sindhunata. Dilema Ysaha Manusia Rasional. Jakarta: Gramedia, 1982.

Siswanto, Joko. Kosmologi Einstein. Yogyakarta: Tiara Wacana, 1996.

Sumantri, Jujun Suria S. Ilmu dalam Sebuah Prospektif, Sebuah Karangan Hakekat Ilmu. Jakarta: Yayasan Obor Indonesia: 1994.

Filsafat Ilmu Sebuah Pengantar Populer. Jakarta: Sinar Harapan, 1995.

al-Suyūṭiy, Jalāl al-Dīn 'Abd al-Raḥmān Abu Bakr, Al-Durar al-Muntasyirat fi alAhādīs/ al-Masyhūrah (cet. II. Bairut: Dār al-Kutub al-'Ilmiyah, 1988.

Shuriye, Abdi O.,'Islamic Position on Physic with Reference to Ibn Al-Haytam" dalam International Journal of Applied Science and Technology, Vol. 1 No. 2; April 2011. Dapat diakses www.ijastnet.com.

al-Shahrasāni, al-Milal wa al-Niḥal, jilid I (Beirut: Dār al-Kutub al-'Ilmiyah, $1369 / 1950$.

al-Tirmidhi, Abū 'Isā Muhammad ibn 'Isā ibn Surah, Sunan al-Tïmidhi, jilid III. Beirut: Dār al-Fikr, 1400 H/1980 M. 
Thiselton, Anthony. C., Horizons in Hermeneutics. Michigan: Zondervan Publishing House, 1992.

Toulmin, S., The Return to Cosmology, Postmodern Science and Theologi of Science. London: Unwin Paperback, 1989.

Watt, W. Montgomery, Islamic Philosophy and theology. Endinburg: Endinburg University Press, 1972.

Whitehead, Alfred North, Science and The Modern World (New York: Mentor Book, 1962.

Yazdi, Mehdi Ha'iri, The Principle of Epistemology in Islamic Philoshophy; Knowledge by Presence. Terj. Yuliani Liputo, Ilmu Hudhuri: Prinsip-prinsip Epistemologi dalam Filsafat Islam, Cet. I: Bandung: Mizan, 1994.

al-Zamakhsyari, Abi al-Qāsim Jār Allah Maḥmūd ibn Umaral-Kawarizimi. alKasysyāf 'an H\}aqā’iq al-Tanzìl wa 'Uyūn al-Aqāwil fi Wujūh aloTa'wïl, jilid iv. Beirut: Dar al-Fikr, t.th.

Zoetmulder, P.J. Manunggaling Kawula Gusti, Panteisme dan Monisme dalam Sastra SulukJawa. Jakarta: Gramedia, 1990. 
